\title{
A FRAMEWORK FOR ANALYSING INNOVATION IN THE FOOD SECTOR
}

Working paper no. 38 November 1995 


\section{A FRAMEWORK FOR ANALYSING \\ INNOVATION IN THE FOOD SECTOR}

Klaus G. Grunert The Aarhus School of Business

Hanne Harmsen

The Aarhus School of Business

Matthias Meulenberg

Wageningen Agricultural University

Erno Kuiper

Wageningen Agricultural University

Tom Ottowitz

Institut für Wirtschafts- und Sozialwissenschaften

Francis Declerk

IGIA Institut de Gestion Internationale Agro-Alimentaire

Bruce Traill

University of Reading

Gert Göransson

Ideon Agro Food 


\section{Preface}

The present text has been prepared by the members of the 'Innovation' subgroup of the EU Concerted Action 'Structural Change in the Food Industry', co-ordinated by Professor Bruce Traill, University of Reading.

The text serves a dual purpose. It is intended as a review of the literature on the determinants of innovation and innovativeness and their impact on business performance, with a special view to the food industry. As such, it stands alone and can be read by itself. But it also serves as the theoretical framework for a series of case studies conducted by the members of the subgroup, which are currently underway. These case studies, interpreted on the background of the concepts detailed in this paper, will allow the derivation of a more detailed framework for the analysis of innovation in the food industry, which will then be amenable to quantitative analysis.

This paper is published as part of the discussion paper series of the Concerted Action. At the same time, it is published as a MAPP working paper. This is to ensure a wide circulation. The authors wel come comments and criticism.

Dunedin, New Zealand, September 1995

Klaus G. Grunert 


\section{EXECUTIVE SUMMARY}

1. There are two major views on innovation. In one view, innovation is closely linked to technological change and to research and development (R\&D) activities; a view prevailing in industrial economics literature. In the other view, mainly taken in marketing literature, innovation is regarded as the detection and fulfilment of unfilled needs and wants of potential customers, presupposing a market orientation of the innovative company. In the food sector, the interaction of $R \& D$ and market orientation can be expected to be a major determinant of innovation and innovativeness.

2. A product innovation is defined as something which is new to the consumer, the distributor, and/or the producer. It can be caused by any changes in the marketing parameters. A process innovation is defined as investments enabling product innovations. Innovations can be more or less successful, as measured by market acceptance of fulfilment of company goals. Companies can differ in their degree of innovativeness, depending on the number and success of their innovations.

3. There is no clear-cut evidence on the relationship between the extent of $R \& D$ activities and business performance, neither in general nor in the food industry. There is some empirical evidence that a higher degree of market orientation leads to improved business performance, although this has not been demonstrated for the food industry.

4. The innovation process of a company is affected by the way in which the company is embedded in networks, clusters, and chains. Companies within an industry also exhibit certain patterns of innovative activities over time.

5. The size of the company may have an impact on its innovativeness, but the relationships is not clear, arguments being raised for a higher degree of innovativeness of both small and large companies. In the food sector, however, there may be reason to believe that small companies are better in invention and development, whereas larger companies have advantages in market introduction and diffusion.

6. Vertical co-operation may improve innovativeness in three ways: downstream vertical co-operation can facilitate the generation of market intelligence, upstream vertical co-operation may facilitate the acquisition of production competences necessary for innovation, and the communicational requirements of vertical co-operation may facilitate market responsiveness.

7. Research on the determinants of success at the project level has identified three groups of factors: the existence of a dearly defined new product development strategy, market focus in the product development process, and the organisation of the product development process, especially a certain degree of formalisation. 
Innovation in the food sector: Between technol ogy-push and demand-pull

Concepts of innovation

Product innovation

Process innovation 5

Innovativeness $\quad 5$

Innovation success $\quad 6$

$\begin{array}{ll}\text { Innovation and business performance } & 7\end{array}$

R\&D and business performance $\quad 7$

Market orientation and business performance 9

$R \& D$, market orientation, and innovation 13

$\begin{array}{ll}\text { The process of innovation } & 13\end{array}$

Innovative potential at the supra-company level 13

Influences on innovativeness at the company level 16

Influences on innovation success at the project level 24

Issues in the analysis of innovation in the food sector 28

References 31 


\section{INNOVATION IN THE FOOD SECTOR: BETWEEN TECHNOLOGY-PUSH AND DEMAND-PULL}

The introduction of new products is widely regarded as an essential element of competition between food companies, and the successful management of new product development a key determinant of business performance. It is estimated that the modern supermarket often carries a product range of 10,000 to 15,000 products and turns over perhaps $10 \%$ or more of these every year. A leading UK food retailer is said to introduce around 1,500 new own-label products alone in 1993, compared with 300 in 1987 (Hughes, 1994).

Innovation is thus regarded as a major source of competitive advantage for a food company. There are two major views on innovation to be found in the economics and business literature. The one is where innovation is regarded as closely linked or even identical with technological change Technological change is viewed as the driving force for wealth creation in modern industrial and service oriented economies, and research and development $(R \& D)$ is considered to be the key factor in technological devel opment, meaning that $R \& D$ statistics can be used as indicators of technol ogical levels of industries or countries. By this score, the food industry is often defined as low-tech, having one of the lowest $R \& D$ to sales ratios of any industrial sector (Traill, 1989). Reported R\&D to sales ratios for large food companies are in the order of $0.5 \%$ in food manufacturing compared with $12 \%$ for drugs, $8 \%$ for electronics, and $4 \%$ for motor vehicles (Commission of the European Communities, 1992). Table 1 shows R\&D to value-added ratios for a number of industries and a number of countries over time.

Table 1. R\&D to valueadded ratios for various industries in 1985 and 1989

\begin{tabular}{|ll|c|c|c|c|}
\hline & & electronics & drugs & motor vehicles & food and drink \\
\hline Denmark & 85 & 9.8 & 13.9 & - & 1.0 \\
& 89 & 12.7 & 18.0 & - & 1.2 \\
& & & & & \\
France & 85 & $?$ & 28.2 & 15.2 & 0.9 \\
& 89 & $?$ & 31.7 & 19.4 & 1.6 \\
& & & & & \\
Germany & 85 & $?$ & $?$ & 7.1 & 1.9 \\
& 89 & 15.6 & 16.0 & 8.9 & 1.2 \\
& & & & & \\
Japan & 85 & 14.7 & 13.7 & 8.8 & 1.6 \\
& 89 & 18.4 & 13.0 & 9.9 & 2.0 \\
& & & & & 1.6 \\
Sweden & 85 & 22.3 & 41.4 & 22.2 & 1.8 \\
& 89 & 33.2 & 41.2 & 14.2 & \\
& & & & & \\
United & 85 & 23.0 & 19.4 & 7.0 & 0.9 \\
Kingdom & 89 & 22.9 & 22.6 & 5.9 & 1.0 \\
& & & & & \\
\hline
\end{tabular}


The other view, adopted mainly in the marketing literature, is that innovation is the detection and fulfilment of unfilled needs and wants of potential customers, using the skills, resources, and competences of the company (Grunert, Hartvig Larsen, Madsen \& Baadsgaard, in press), a process which is often called the market-orientation of the company. The marketing literature has paid much attention to the non-technological aspects of innovation. New product management has become a very important element of marketing operations (Urban, Hauser \& Dholakia, 1987, and others). Market penetration of new products has been studied in new-product diffusion models (Mahajan et al., 1993), product life cycle type models and adoption models (Nijkamp, 1993). In the marketing literature, it is argued that $R \& D$ does not guarantee innovative success. It is not only important to have facilities to acquire the technical intellectual property in order to innovate, like R\&D, licensing, acquisitions or joint ventures. It is also of particular importance that these intellectual inputs should interact with the needs in the market.

In a thorough analysis of the literature from marketing, organisational behaviour, business strategy, research management, innovation, and new product management, Gupta et al. (1986) concluded that a balanced R\&D-marketing coordination is rather crucial to achieve innovation success. That $R \& D$ is only one among several factors determining successful innovation holds for the food industry at least as much as for other industries, if not more. It has been pointed out that tastes and habit for food are part of the cultural heritage and change only slowly, making successful innovation difficult. Evidence cited in support for this includes the high failure rates for new product introductions, quite protracted penetration curves for new products which became successes in the final run, and econometric analyses estimating that taste changes account for only very small proportions of the overall variation in the demand for food products (Søgaard, 1994). I nvestment into innovation and product development is therefore not an easy key to success in the food industry. The new products, and the skills, resources and competences allowing their production, have to be 'right' for the market to be served. In addition to R\&D skills, market-orientation skills are therefore an important component of a food company's innovation activities.

Similar observations in other sectors, that $R \& D$ alone does not explain innovation, has led to a widening of the field of investigation, so that the understanding of innovation has recently changed dramatically. Interactive models now emphasise the central role of industrial design, the feed-back effects between downstream and upstream phases of innovation and the numerous interactions between science, technology and other innovation-related activities within and among companies.

This paper reviews some of the recent literature on the interaction of $R \& D$, market orientation, innovation, and business success. The overall structure of the paper is depicted in figure 1: both R\&D and market orientation, and the way in which they are co-ordinated, are regarded as major determinants of innovation, which, if it leads to customer acceptance, can be regarded as a major determinant of business performance. The paper begins by spelling out the concept of innovation and the different types recognised in the literature, noting especially the difference between innovation, which is something characterising a particular project, and innovativeness, which characterises a company as a whole. It then reviews the literature which has tried to establish a direct link 
between $R \& D$ and business performance, and the literature which has tried to establish a direct link between market orientation and business performance (the dotted lines in figure 1). It proceeds to look more closely at the process of innovation and the determinants of innovation success, distinguishing between the project, company, and supra-company levels. It finishes by coming back to the overall model and lists a number of unresolved issues.

It should be noted that most of the literature we drawn upon does not explicitly address the food industry. It will be made clear which of the results and theories mentioned refer explicitly to the food industry and which are of a more general nature. The theoretical treatment in this paper will be the basis for a series of case-studies of innovation in large and small food companies in a number of European countries. By the interaction of the theoretical framework and the empirical analysis it is hoped to be able to formulate a more full-fledged theory of innovation in the food sector.

Figure 1. A framework for analysing innovation in the food sector

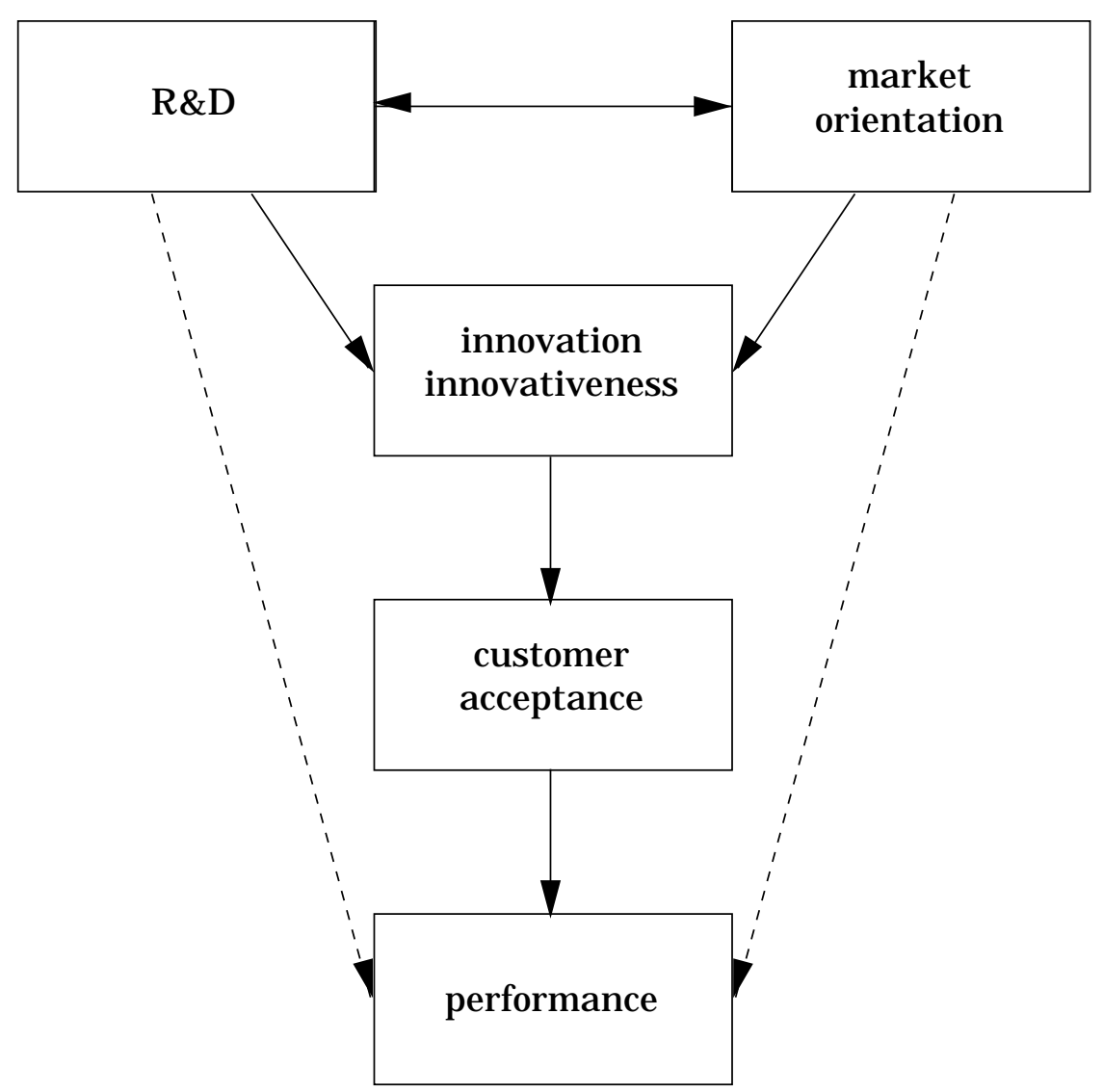




\section{CONCEPTS OF INNOVATION}

\section{Product innovation}

According to Kotler (1991) "an innovation refers to any good, service, or idea that is perceived by someone as new. The idea may have a long history, but it is an innovation to the person who sees it as new."

A product may therefore be an innovation to one person but not to another. In the context of consumer goods, it makes sense to distinguish between three groups of actors, who may or may not regard a given product as new: consumers, distributors, and producers. Depending on who among these three groups perceives a product as new, we may then distinguish several types of innovation, as in figure 2. Newness to consumers will largely depend on whether consumers bel ieve the product to offer more value relative to existing products and to price. Newness to distributors will depend on their expectations of how consumers perceive newness, but may, in addition to that, be influenced by factors important to retailing, like storage characteristics, logistics, and contribution to chain positioning, which may not contribute to consumers' perception of newness. Newness to the producer will among other things depend on whether the product required process innovations in the company, ie, the development of skills and resources not previously available, so that even a product not perceived as new at all by consumers and distributors may be regarded as new by the producer.

In the view adopted here, a product innovation does not necessarily require a change in the physical product - all marketing parameters can lead to some actors regarding a product as new. A lasting price reduction may be an innovation in the eyes of consumers, because it changes the value-for-money perceived in the product, and it may be an innovation in the eyes of the producer when it is based on a cost-saving change in production technology. Likewise, a major change in advertising message can lead to an innovation when it, in the eyes of the customers, leads to a major repositioning of the product. However, temporary price reductions and minor changes in advertising copy will not usually lead to the product being regarded as new.

Figure 2. Innovation and newness

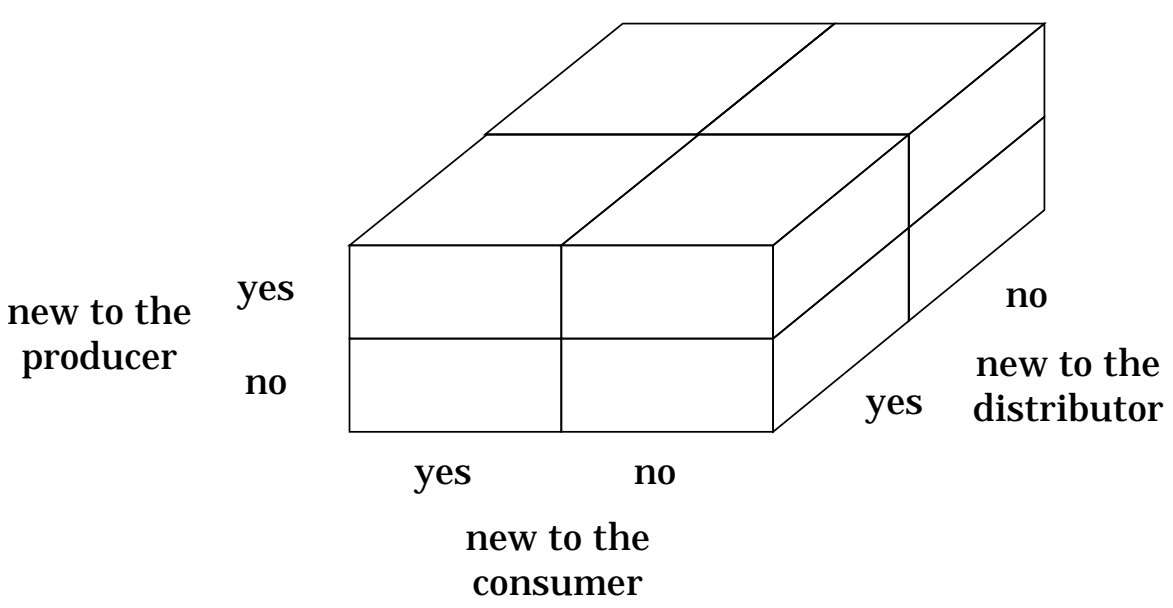


Innovation may be related to invention. As soon as an invention is commercially introduced, it is referred to as an innovation. Innovation may also refer to the process of developing an invention into an innovation, see Davies (1988), J ohne (1985) and others. But we do not endeavour to discuss whether a product innovation also presupposes an invention - inventions are usually perceived as something emanating from $R \& D$, and, as argued above, not all product innovations have to be based on $R \& D$.

\section{Process innovation}

It is usual to distinguish between product innovations, which create new products and services, and process innovations, which reduce the cost of producing existing products or enable the production of new products, see Davies (1988), J ohne (1985), Tirole (1988) and others. However, the distinction is not always clear-cut, since process and product innovation often go hand in hand. Here a process innovation is defined as an investment into a company's skills, resources, and competences, which allows the company to bring about product innovations. Given the view that has been adopted on product innovation, this covers both cost-saving changes in production processes and the introduction of new technology which allows the production of a range of products quite different from the existing one. Also, process innovations may refer to technological innovations, ie, be based on $R \& D$, but may also refer to innovations with regard to market-orientation skills and competences. The introduction of a market intelligence system, or the reorganisation of the product development process, both of which may enable the company to become better in developing product innovations, may therefore likewise be regarded as process innovations.

\section{Innovativeness}

The term innovativeness can be used at two levels: as a characteristic of a particular innovation, and as a characteristic of a company.

Various classifications of innovations according to degrees of innovativeness have been proposed. One distinction is between radical (or revolutionary) innovation and incremental (or evolutionary) innovation. Henderson and Clark (1990) distinguish between modular innovation, which represents a substantial step-change in the design of a component within a product consisting of many components, but where the newly designed component fits comfortably into the previous configuration of the product, and architectural innovation, where the components are much the same, but their technical interrelationship shows greatly enhanced sophistication (Fairtlough, 1994). Booz, Allen \& Hamilton (1982) identified the following six categories of new products and services in terms of their newness to the company and to the marketplace: 1 . new-to-theworld products, 2 . new-product lines, 3. additions to existing product lines, 4. improvements in revisions to existing products, 5. repositionings, 6. cost reductions. Basically, all these distinctions boil down to two dimensions: how new is an innovation to the market, and how new is it from a technological perspective, corresponding to the two sources of innovation in figure 1 . 
In management literature (Sneep, 1994) much attention has been given to the innovation power, or innovativeness, of a company. Cozijnsen (1989) identifies four dimensions in his concept of innovativeness: innovation speed, innovation willingness, innovation capacity and innovation quality. The quality of innovations as a criterion for innovativeness might be conceived as the number of successfully marketed new products, as new product sales as a percentage of total sales, or as the contribution of new product sales to cash flow or profits. A candidate for measuring innovative capacity might be R\&D expenditure as a percentage of total sales, which, in the light of the discussion above, should be complemented by evaluations of the organisation of innovation in the company, such as the relationship between marketing and $R \& D$ and other aspects of market orientation. Willingness to innovate is an element of the corporate culture and can be related to general management's stimulation of innovativeness by fostering flexible organisation and avoiding bureaucracy in the company, and by stimulating and adequately remunerating innovative employees. Finally, speed of innovation is related to the organisation of the innovation process in the company.

In the following, we will employ the term innovativeness in the sense of innovation quality, ie, as a company characteristic which can be measured, among others, by the number of product innovations launched in a given period, the number of product innovations launched which have become long-term successes, the average radicality of the company's product innovation, and the percentage of sales accounted for by new products. The other three dimensions will be treated as possible determinants of innovativeness.

\section{Innovation success}

Innovation success is a rather diffuse concept, which has been operationalised in many different ways. Based on both a literature review and an empirical study of management practice, Griffin and Page found as many as 75 different new product success and failure measures used by academics and practitioners (Griffin \& Page, 1993). Also Craig and Hart (1992) have pointed to the confusion concerning measuring innovation performance and point to the fact that currently innovation performance measurement typically differs according to the measures used (financial versus non-financial), the level of analysis (project versus program performance) and, for research investigations, al so the source of data (self, expert or peer assessment) and the data-collection method (eg, personal versus mail questionnaires). Apart from the many different measures used, an important issue concerns different dimensions of innovation success. Innovation success is often used as a one-dimensional concept, but Cooper and Kleinschmidt (1987) found three independent dimensions that characterise new product performance (financial performance, opportunity window, and market impact), which raises the question whether there are different determinants of these dimensions of innovation success.

In this paper, we propose that innovation success can be measured in two dimensions. The first is market acceptance: to what extent do customers perceive a product innovation not only as new, but as superior to existing products, and to what extent does this lead to purchase intentions, to trial purchases, and to repeat purchases? The other dimension refers to the extent to which the 
innovation has contributed to a realisation of the company's goals. To the extent that these goals are sales-related, this will be related to market acceptance, and the same will, to a lesser extent, be true for financial goals. However, a company may also have other goals with innovation - it may, for example, be part of a process of organisational learning and competence building, and hence contribute to a company's goals even when market acceptance is low.

\section{NNOVATION AND BUSINESS PERFORMANCE}

In this section, an attempt is made to look at the relationship between innovation and innovativeness in a company and its performance, as measured by return on investment (ROI), return on sales (ROS) or other measures of profitability. It is found, however, that the literature is basically void of treatments of this relationship when innovation is viewed in the way defined here, namely as the interaction of $R \& D$ and market orientation. What is found, instead, are treatments of the relationship between $R \& D$ and business performance, and treatments of the relationship between market orientation and business performance. These will be discussed in turn.

\section{$R \& D$ and business performance}

The relationship between $R \& D$ and business performance can be analysed directly or indirectly. One can look into how various degrees of expenditure on $R \& D$ are correlated with measures of business performance, but can also look at how expenditure on $R \& D$ is related to the innovativeness of the company and its competitive position, which in turn can be related to performance (Day \& Wensley, 1988; Grunert, Hartvig Larsen, Madsen \& Baadsgaard, in press).

A whole research area within the broader area of innovation research has been built on the basic presumption that a high investment in R\&D activities will lead to a high company performance and general economic growth for society (Sundbo, 1994). Most empirical investigations have investigated this link indirectly, eg, by measuring the relationship between $R \& D$ spending and number of patents, which is regarded as an indicator of performance due to the possibility for monopoly rents while the patent is pending. These investigations have, however, generally not been able to identify a clear relation between $R \& D$ and performance (Scherer, 1984).

Looking more directly at this relation, Cooper (1984) has investigated the link between different innovation strategies and business performance. Five clusters of innovation strategies were identified and linked to performance, measured as impact (percentage of sales accounted for by products introduced over the past five years), success rate, and financial performance (a total of nine measures were used). Heavy $R \& D$ spending played an important part in two of these five strategies. However, when linked to performance, these two strategies performed most poorly and were deficient on most performance measures. Of the two strategies that performed best one actually had the lowest relative R\&D spending, but by sticking to a conservative low budget strategy these firms had a profitable programme with a high success rate, while the impact on company sales was quite low. The best performing strategy, which came first on nearly 
every performance measure, had an approach where technological prowess was balanced with a strong market orientation. While they were technologically sophisticated, their direct $R \& D$ spending was not large. The clusters of strategies in this study were based on 66 strategy variables of which $R \& D$ spending was only one. No clear conclusions can therefore be drawn, but the results at least question the presumed positive link between $R \& D$ and performance.

The PIMS studies have also investigated the link between $R \& D$ and business performance and reached a number of general conclusions. High R\&D spending depresses ROI when market share is weak, $R \& D$ is most profitable in mature slow growth markets, and high $R \& D$ plus high marketing expenditures depresses ROI (Abell \& Hammond, 1979). Also these results question the presumption of a positive link between $R \& D$ and business performance. It should also be noted that the direction of causality in such studies is far from clear: high profits may lead to increased spending on $R \& D$, which again may lead to new products which enhance profits (Scherer \& Ross, 1990).

A recent Danish cross-sectional study has investigated how $R \& D$ intensity relates to measures of innovativeness, namely to product innovation intensity and to innovation performance, measured as the percentage of sales coming from unchanged, slightly modified, and radically modified or new products (Christensen \& Kristensen, 1994). As can be seen in table 2, the data show a fairly strong relation between $R \& D$ intensity and product innovation intensity, while the relation between $R \& D$ intensity and innovation performance is less clear.

Table 2. Relationship betwen $R \& D$ and innovativeness

\begin{tabular}{|l|l|l|l|}
\hline Industry & $\begin{array}{l}\text { Number of } \\
\text { product } \\
\text { innovative firms }\end{array}$ & $\begin{array}{l}\text { New/changed } \\
\text { product part } \\
\text { of sales }\end{array}$ & $\begin{array}{l}\text { R\&D } \\
\text { intensity }\end{array}$ \\
\hline Food & low & low & low \\
Textile & high & low \\
Furniture/wood & low & medium & low \\
Paper/graphic & low & low & low \\
Oil (chemical/mineral) & high & medium & high \\
Plastics/rubber & medium & medium & low \\
Stone/glass/clay & medium & low & medium \\
Iron and steel & medium & low & low \\
Mechanical & medium & medium & medium \\
Transportation & medium & high & medium \\
Telecommunication & high & high & high \\
Electronics & high & high & high \\
Raw materials & low & low & low \\
\hline
\end{tabular}

(adapted from Christensen \& Kristensen, 1994) 
The relationship between $R \& D$ and performance is affected by the fact that $R \& D$ is risky. At the corporate level, five types of risks in the $R \& D$ process can be distinguished: research risk, time risk, technological advancement risk, quality risk, and market risk (Yon, 1992).

Research risk is the risk of "not finding", even by increased research efforts. That risk is augmented by the risk of finding some positive result that enlarges knowledge, but which cannot be applied successfully within a given horizon, or which does not fit the core business of the company.

Time risk concerns the time required by the research. Delays increase costs and reduce profits.

Technological advancement risk is the risk of not being the first to find the expected result. It occurs when a competitor is the first to find the expected new process, product or substitute.

Qual ity risk means that R\&D efforts may provide different levels of productivity gains at different times. One technology may seem full of promise and superior to another technol ogy at its introduction, but further research efforts may result in higher productivity gains with the other technology in the long term.

Market risk refers to the risk that an R\&D-based innovation, even when the $R \& D$ goals have been reached, will not necessarily be accepted by the market.

All of the studies referred to above are of a general nature, looking at relationships across industries. There is only qualitative evidence on the relationship between $R \& D$ and performance in the food industry, which has a number of peculiarities. For example, the ability to patent food products is often questioned. Biotechnology research is faced with patenting problems, since the patenting of life (living molecules used in the food process of yoghurts, for example) is not allowed. But Yon (1992) estimates that, in the food sector, technological advance relative to competitors is usually more crucial to generate profits than patent protection. Few technological ruptures exist in the food industry, but the ones which have occurred have had considerable impact on competitive positions. For example, this was the case with biological processes instead of chemical processes in producing aspartame, or with frozen food instead of canned food.

There is therefore no clear-cut evidence on the relationship between $R \& D$ and business performance, neither in general nor in the food industry. The risk of the innovation process implies that innovation management, and especially the way in which technological and production skills are related to market opportunities, become especially important. We now turn to the concept of market orientation and its relationship to business performance.

\section{Market orientation and business performance}

As argued at the beginning of this paper, successful innovation in food companies requires at least two types of skills: R\&D skills and market-orientation skills. R\&D skills ensure the competences to devel op new technol ogies. Marketoriented skills ensure that innovations correspond to market needs. 
Market orientation is therefore important for innovation in food industries. Fundamentally new innovations are scarce in food production. Many innovations are modifications of existing products and are demand driven innovations, ie, the innovation process has been triggered by retailer demands or by consumer research. Consumer trends in needs and wants with respect to taste, convenience, health, environmental aspects, offer opportunities to food producers. Therefore, a market orientation might contribute substantially to product innovation.

Market orientation is at present a popular concept in marketing. A company is called market oriented if it systematically monitors market developments, both customers and competitors, and fits products and services to these developments. Scientific interest in market orientation has stimulated marketing scholars to define the concept, to develop measures of market orientation, and to analyse its impact on business performance.

Lichtenthal and Wilson (1992) report how market orientation is defined in practice by various companies: "adopting a market-based management philosophy.....creating of a marketing community within the company.....an external market perspective throughout the company which requires changes in behaviours, processes, skills, context of decision making and reward structures..... one which is highly customer oriented and has a strategic focus."

Dreher (1994) distinguishes a philosophical approach and a behavioural approach to the concept of market orientation. In the philosophical approach, market orientation is regarded as a state of mind, as a set of knowledge, beliefs and attitudes guiding the behaviour of individuals in companies. In the behavioural approach, the manifest behaviour of and in companies is used to indicate the degree of market orientation. The latter approach is taken by Narver and Slater (Narver \& Slater, 1990; Slater \& Narver, 1994) and by Kohli and J aworski (J aworski \& Kohli, 1993; Kohli \& J aworski, 1990).

Narver and Slater (1990) argue that "market orientation consists of three behavioural components - customer orientation, competitor orientation, and interfunctional co-ordination - and two decision criteria - long term focus and profitability." They developed a three-component model of market orientation, whose construct validity has been tested. Kohli and J aworski (1990) distinguish three core themes in market orientation, namely customer focus, co-ordinated marketing, and profitability, and three elements, namely intelligence generation, intelligence dissemination, and responsiveness. Market orientation is defined by these authors as "the organisation-wide generation of market intelligence pertaining to current and future customer needs, dissemination of the intelligence across departments, and organisation-wide responsiveness to it." They developed a 20-item market orientation measure (MARKOR), which assesses the degree to which a strategic business unit (SBU) (1) engages in multi-department market intelligence generation activities, (2) disseminates this intelligence vertically and horizontally through both formal and informal channels, and (3) develops and implements marketing programs on the basis of the intelligence generated. Key attributes of the measure include (1) a focus on customers of the SBU and the forces that drive their needs and preferences, (2) activity-based items, not business philosophy, and (3) a demarcation of a general market orientation factor and associated component factors (Kohli, J aworski \& 
Kumar, 1993). Ruekert (1992) uses a definition of market orientation which is similar to the ones just named, but adds the explicit focus on strategic planning at the business unit level.

Different studies have been carried out in order to examine the impact of market orientation on performance (see Grunert, Hartvig Larsen, Madsen \& Baadsgaard, in press). The findings of the most important of these reported in the literature are briefly reviewed.

In a large scale empirical study across industries, J aworski and Kohli (1993) find that market-oriented organisations have a senior management which is very committed to and continuously puts emphasis on listening to customers and being very sensitive to competitors. They rely very much on market-based factors (customer satisfaction, customer relationships, sensitivity to competitive moves, etc.) when evaluating and rewarding managers. Furthermore, marketoriented organisations are characterised by being not highly centralised and by having high interdepartmental connectedness and low conflict levels among different departments.

The empirical findings confirm the hypothesis that market-oriented companies exhibit higher organisational commitment, job satisfaction, 'esprit de corps', and perceived overall business performance. The linkage between market orientation and perceived performance appears to be robust across environmental contexts that are characterised by varying degrees of market turbulence, competitive intensity, and technological turbulence. The study does not, however, give support to the notion that market-oriented organisations have higher market shares than organisations with low market orientation. $\mathrm{J}$ aworski and Kohli argue that this lack of support may be due to lag effects and low validity of the measure. They end up concluding that "it appears that managers should strive to improve the market orientation of their businesses in their effort to attain higher business performance."

Ruekert (1992) finds support for a positive relationship between market orientation and long run business unit performance in a study involving a large number of managers from five business units in a large, high technology company. His operationalisation of market orientation emphasises strategy development and execution; otherwise, it follows the ideas of Jaworski and Kohli quite closely. Ruekert compares the most profitable business unit with the least profitable one. He finds strong evidence that the most profitable unit has a higher market orientation. However, due to his research design, it is not possible to control for other types of explanations for differences in performance (such as type of market, nature of competition, etc.).

Narver and Slater (1990) examined 140 business units in the forest industry, including commodity products (eg, lumber, plywood, logs) as well as noncommodity products (eg, hardwood cabinets, laminated doors, roof truss systems). Market orientation was measured as a simple average of the sum scores of the responses to items indicating customer and competitor orientation and also interfunctional co-ordination of business units. Performance was measured as the top managers' assessment of the return on assets in relation to that of all other competitors in the business unit's served market. 
For non-commodity businesses, Narver and Slater find a statistically significant, monotonically increasing relationship between market orientation and the subjective assessment of return on assets. For commodity businesses they find a statistically significant, but non-linear relationship. The best performers are found in the group of business units with high market orientation, followed closely (no statistically significant difference) by those with low market orientation, leaving the businesses with medium market orientation as the worst performers. The highly market-oriented businesses seem to gain profitability through customer retention, human resource management and top management consensus and flexibility. The businesses with low market orientation seem to gain profitability through other means, namely size and management longevity, probably including some kind of cost leadership - or perhaps close relations to their industrial customers (which is often an effective way of building entry barriers).

While some authors (eg, Miles \& Snow; 1978) argue that market orientation is not profitable under all circumstances, in some environments even simply uneconomic, Narver and Slater conclude that the highest degree of market orientation is associated with the highest profitability in both groups; accordingly, they support the notion that market orientation is relevant in any market environment. They end up saying that "the appropriate question is not market orientation per se, but rather what a business perceives to be its optimal degree of market orientation within its current and expected market environment."

In order to become more market-oriented, Day (1994) argues that "the most distinctive features of market-driven organisations are their mastery of the market sensing and customer linking capabilities. A comprehensive change program aimed at enhancing these capabilities includes: (1) the diagnosis of current capabilities, (2) anticipation of future needs for capabilities, (3) bottom-up redesign of underlying processes, (4) top-down direction and commitment, (5) creative use of information technology, and (6) continuous monitoring of progress."

The studies referred to above do not refer specifically to the food industry. The only study focusing purely on food companies was carried out by Madsen (in press), who examined the structure and behaviour of 24 Danish food companies. After classifying them according to their historical record of return on sales, he compared the high performers and low performers. The high performing food companies are quite small (average 37 employees compared to 142 employees in the low performing group) and have a very simple organisational structure. They have a top management which is relatively less growth-oriented, proactive and less used to make decisions based on market information; furthermore they are more risk averse and less decentralising. The high performers are very much oriented towards their domestic market and only involve themselves marginally in foreign markets, which they serve mainly via distributors. As a consequence the high performers have only very little market contact outside their domestic market.

It seems that the high performers have invested more in internal competences (production and logistics) than in market orientation. Madsen sums up by saying that the findings are somewhat contradictory to previous findings, but that they give rise to further reflection, since it seems that proactivity and market orientation are apparently not al ways the key to success. 
Madsen points to three basic weaknesses of his study. First of all, his measure of performance relates to past performance, whereas his measures of strategy and behaviour refer to actual strategy and behaviour, so that causal relationships cannot be revealed. Secondly, the return on sales measure is taken from annual reports of the respondents, which may be difficult to compare across companies. Thirdly, his measures of market orientation are quite crude, involving only very few operationalised variables. These qualifications may explain why Madsen's findings are somewhat in contrast to studies carried out in other industries than the food industry.

\section{R\&D, market orientation, and innovation}

There is thus some general, although not unequivocal, evidence that both $R \& D$ and market orientation are positively linked to business performance. However, this relationship would be much better understood if these links were not analysed separately, but when analysis would concentrate on how R\&D and market orientation interact in the company's innovation processes, which in turn are related to performance.

Some authors implicitly recognise the importance of market orientation for innovation. For instance Shaw (1994), argues that “...a company start-up strategy which consciously stresses learning about customers is preferable to a strategy which initially focuses on other market activities." Littler (1994) concludes about the function of marketing in the innovation process "This involves constant close liaison with potential customers throughout the development process...". However, it is also interesting to note that, according to some authors, looking to the needs of the established market may prevent fundamental innovations (eg, Utterback, 1994).

The next section of this paper looks at literature and empirical findings on the innovation process, keeping in mind the importance of the $R \& D$ and market orientation components.

\section{THE PROCESS OF INNOVATION}

The process of innovation is analysed at three levels: at the supra-company level, at the company level, and at the project level.

\section{Innovative potential at the supra-company level}

Porter (1990) argues that apart from factor costs a great number of other variables influence the competitiveness of nations. In his so-called "Diamond" model, Porter argues that the following factors have an impact on the competitiveness of nations in international markets: a) factor conditions such as labour and infrastructure, b) demand conditions, such as the type of domestic market (are consumers critical or not), c) related and supporting industries, such as input supplying industries, d) firm strategy, structure and rivalry (eg, is the domestic market competitive), e) government policies (subsidies, protection, legislation with respect to the environment etc.). Porter argues that the position 
of a country on the world market is a criterion for its competitiveness. In his opinion this is a better measure than rentability, since the latter can be affected by regulations.

Marceau (1994) distinguishes three sets of lenses which are useful to describe and evaluate the innovation processes in a given country. These are based on the analysis of clusters, chains of production, and complexes. Clusters of companies producing highly interrelated products, being involved in product innovation, profit a great deal from technical and organisational co-ordination. The presence of clusters of qualified companies will enhance the innovative power of a country. Clusters of companies and of expertise seem important for innovation in the food sector too, since innovating companies do not dispose of all necessary skills themselves. This has been shown for the Danish food sector by Kristensen (1992). The chains of production approach refers to identifying the weak links in the chain from producer of raw materials to the seller of the final product to the consumer and how the weakest links can be improved. Complexes, finally, are conceived by Marceau (1994) as "...formalised or informal networks of cooperation between...producers (firms), public sector research organisations, users (consumers, other firms) and regulators (governments of all levels)."

A similar approach to describing the innovative structure of a country or region is what Cooke and Morgan call the creative milieu. They distinguish three ways of structuring the milieu: the directed model, typically found in France, like the Technopolis near Grenoble, the grassroots approach, like municipal technology centres in Japan and the silicon landscapes of California, and the network paradigm, like the hierarchy of innovation institutions in Baden-Württemberg (Cooke \& Morgan, 1994).

The usefulness of the systems approach to innovation is underlined amongst others by Carlsson (1994): “.... by examining technological systems as opposed to merely studying their constituent parts (users and suppliers, $R \& D$ infrastructure, etc. ), it is possible to discover the sources of new technologies, to analyse the diffusion and utilisation of new technology and the conditions (especially the institutional arrangements) under which these processes take place, and therefore to gain insight into the relationship between technological change and economic growth." Rothwell argues that we have reached the fifth generation of innovation processes in the evolution: technology push (1950 - mid 1960s), market pull (late 1960 - early 1970, "coupling model" (mid 1970 - early 1980), integrated model (not sequential activities, but parallel models of innovation, functional integration), and finally systems integration and networking (Rothwell, 1994). According to Powell (1990), the approach of networking differs from co-ordination of innovative activities by market forces or by central planning. Characteristic of networking are that activities of actors of the network are complementary and actors are interdependent, their communication is based on a relationship, conflicts are solved by reputation/reciprocity, flexibility of the operation is limited, participating actors have a strong commitment to the network and perceive the network as a win-win relationship.

It is argued that at present in many fields, like in biotechnology, innovations are generated by a network of companies. Sneep (1994) concluded that the institutional network, in particular the relations with research institutes, universities and agricultural boards, is important in innovation management of Dutch agro-food 
companies. Similar results have been reported in Sweden by Gissén and Nelsson (1992). Networking is enhanced by the evolution of marketing organisation. In discussing the evolution of marketing organisation, Achrol (1991) distinguishes two forms of marketing organisation: "The marketing exchange company is the organising hub for market information and complex exchanges. The marketing coalition company is the hub for organising a division of function among an alliance of specialist firms." He argues that new marketing organisations may be characterised as trans-organisational systems, ie, organisations which “...are not simply exchanging finished products, but exchanging critical skills and information, and involve reciprocal functions and obligations across firms." According to Webster (1992) "..the network paradigm is built around the assumption that small is better, that each part or process of function should be the responsibility of a specialised, independent entity, efficiently organised and managed,...".

As an example for the importance of networks in the innovation process, Biemans (1992) has shown that product development of new products in the Dutch medical equipment industry takes place within complex networks, consisting of an internal network of $R \& D$, marketing, quality control and production co-ordinating both internally and with external parties as users, subcontractors, and universities, who again each have their internal network. Biemans concludes that the complexity of innovation networks differs on a number of different criteria and that the level of complexity has implications for the functioning of organisations within networks. He also comes to the conclusion that companies that develop new products within networks commit the same traditional mistakes as many other companies in the development work, eg, letting technology dominate over marketing or performing pre-devel opment activities inadequateIy. Innovating within networks can give a number of advantages (like a higher degree of specialisation and correction of mistakes), while there are also a number of potential disadvantages (like friction, delays and duplication which are difficult to manage within the network).

Various authors have stressed the dynamics of the innovation process. Utterback (1994) laid out a model of the dynamics of innovations in industry, which hypothesises that the rate of major innovation for both products and processes follows a general pattern over time, and that product and process innovations share an important relationship. This model states that the rate of product innovation in an industry or product class is highest during its formative years, the "fluid phase". In this fluid period a great deal of experimentation with product design and operational characteristics takes place, and less attention is given to the processes by which products are made. The period of fluidity gives way to a "transitional phase" in which the rate of major product innovations slows down and the rate of major process innovations speeds up. At this point, product variety begins to give way to standard designs that have either proven themselves in the market place as the best for satisfying user needs, or designs that have been dictated by accepted standards, by legal or regulatory constraints. Finally, some industries enter a "specific phase", in which the rate of major innovation dwindles for both product and process. These industries become extremely focused on cost, volume, and capacity; product and process innovation appears in small, incremental steps. A similar model, relating this devel opment over time to the development of profitability, has been proposed by Yon (1992). Three stages of technological development are distinguished: 1) introduction of a new technology, 2) progressive reduction in unit-cost, and 3) 
completion of technology. At the introduction of a new technology, important preliminary research efforts are necessary to gather all the know-how required to start the innovation process and obtain a modest pay-off, which may be lower than pay-offs from existing technol ogy. Hence, the introduction of the new technologies leads to smaller productivity gains than those that are obtained with the existing technology. As soon as the process is better controlled and optimised, economies of scale are realised and unit costs decrease. At the completion of a technology, every research effort only generates small productivity gains. The technology is then totally mature and the only way to get further profits is to introduce a new technology.

On a company level, dynamic models of the Utterback type imply that small companies have a tendency to initially focus on product innovation, grow larger and shift emphasis from product innovation to process innovation to reach large scale low-cost production as the business matures (Abernathy \& Utterback, 1978). The implied determinism in this has been criticised from different angles, for example by Clark and Staunton (1989), who claim that the law-like status this model has achieved does not correspond with empirical knowledge on evolutionary patterns. Pavitt (1986) claims that the model is best suited to describe the evolutionary pattern for mass markets characterised by homogenous consumer needs, but that it generally offers a poor description of evolution on most other markets. Frøslev Christensen et. al (1990) found in a Danish study that the growth phase of manufacturing companies seldom implies a transition from small-scale production to mass-production. Their explanation for this is that the companies either deliberately keep away from the large markets and follow a niche strategy or that they - if they try expansion - run into trouble due to financial and organisational problems as well as the heavier competition on the broader market. Even if companies are quite innovative, Frøslev Christensen et al. conclude that they have a tendency to remain small and stay within their domains (1990).

Cases of large mass-producing companies that increasingly stress continuous product development (Takeuchi \& Nonaka, 1986) and companies pursuing niche markets (Teece, 1988) also go against the evolutionary pattern implied by Abernathy and Utterback. Company strategies, lack of resources, product and demand related factors have been shown to modify or change the pattern of industrial evolution companies experience over time. The evolutionary pattern of industrial innovation is therefore far more complex than the initial Utterbackmodel implied.

All of the above is based on general reasoning, and empirical evidence, when available, does not refer to the food industry.

\section{Influences on innovativeness at the company level}

Much of the literature on the influences on innovativeness at the company level has its roots in the industrial economics literature and relationships between market structure and innovation as an aspect of market conduct. A central variable in this context has been the size of the company. It should be noted that much of the research cited in the following is based on high technology industries, and that innovativeness is largely equated with R\&D. 
The effect of company size

There are two basic trains of thought as to which is the more innovative company size. Most of the literature and data available do not refer to the food sector specifically. Nevertheless, what can be found may help get some indication of what type of relationship may be expected between company size and innovativeness.

Schumpeter (1939) claimed that the possibilities for large companies to act in a monopolistic way increase their willingness to take on the risks of innovative processes. In Schumpeter's view of the world, an entrepreneur is continually looking for new products and new markets (see also Ansoff, 1965) as well as for new or improved production and distribution processes. A successful innovation provides the entrepreneur with a temporary monopoly that will generate profits. After some time, these profits diminish when other companies enter the market by imitation or adoption. Therefore, in the meantime, the entrepreneur is searching for another innovation that has to create new monopoly profits. This view is shared by the group of neo-Schumpeterians, stating that large companies are basically more innovative than small-sized ones (Galbraith, 1952; Lilienthal, 1953; Villard, 1958). This is supposed to be due to the fact that

- management is highly qualified,

- by pursuing several innovation projects at the same time, failures will be compensated by successes,

- large companies are able to employ a sufficient number of qualified scientists and technicians,

- research staff is able to concentrate on research issues rather than on daily • routines,

- financing innovations by bank loans is easier,

- comprehensive distribution and servicing facilities for introducing new products available.

Rothwell and Dodgson (1994) sum these factors up as material advantages, which at the same time are the major hindrances towards innovativeness of SMEs (see also Behrens-Ramberg, 1985; Leder, 1989; Mensch, 1989; Scherer, 1984). Possible structural problems of SMEs are:

- innovative activities are discontinuous and therefore there is a lack of formal management skills,

- there is a lack of time and resources - the minimum of personal and financial capacities is frequently not being reached, therefore the extent of the innovations is low and thus bears the character of improvements or adaptations,

- there is no basis for interdisciplinary research, 
- the low financial budget does not allow major innovations - especially ones which require a long developing process,

- the number of innovative projects has to be low, which does not allow for spreading the risk related to innovations,

SMEs do not have sufficient information regarding legal regulations, scientific knowledge, possibilities for financial support, development of markets, possibilities of diversification, developments in other countries, etc. (Geschka, 1990; Rothwell \& Dodgson, 1994; Staudt, Bock \& Mühlemeyer, 1992).

The post-Schumpeterians (Rothwell, 1985; Rothwell \& Zegfeld, 1982; Scherer, 1984; Shumaker, 1973) have presented a series of arguments against this view. As Scherer (1984) puts it, "smaller firms are disproportionately prolific contributors to the generation of important technological innovations. Large companies barely pull their weight." SMEs are supposed to be market makers, whereas large companies tend to take over their innovations and imitate them if the potential market volume allows large scale production (Hambüchen, 1988). Tirole (1988) states “... aside from any strategic considerations, the monopolist gains less from innovating than does a competitive firm, because the monopolist 'replaces himself' if he innovates, whereas the competitive firm gets a monopoly. This result follows from the different initial situations. A monopolist tends to 'rest on his laurels'. This property, which we owe to Arrow, is called the replacement effect, which in more simple terms, seems to indicate that the motivation of the staff in smaller companies is higher."

It has alternatively been argued that SMEs have behavioural advantages over large companies, enabling them to react to a change in the market more quickly, because

- there is little bureaucracy, with a rather simple and focused organic organisational structure,

- commitment and motivation of the managers is higher; they themselves are active in planning and realising innovations; they take higher risks and motivate their staff constantly,

- SMEs are more exposed to competition, which forces them to react quickly on changing market requirements,

- the costs for their innovation projects - and especially their overhead costs are mostly lower than in large companies,

- $R \& D$ efficiency is much higher; they do not produce know-how that they will not use in the short range,

- SMEs grow through niche strategies and frequently specialise either in their technology or in their orientation towards customers (Geschka, 1990; Rothwell \& Dodgson, 1994). 
As the degree of innovativeness in the food sector may be considered rather low, innovations of SMEs are more likely to bear the character of imitations. Galizzi and Venturini (1994) made low levels of research and development, an incremental character of product innovations, a low technological level of the food industry, and a relevant flow of new food introductions responsible for this. They believe that these characteristics, plus - as a consequence - the low risk and low fixed costs, would actually favour the competitive position that the SMEs have over large companies. However, the high degree of market orientation requiring market research and tests, introductory advertising and other market expenditures can determine relevant sunk fixed costs particularly if most of the elements of the marketing mix require large investments and have scale economies (Galizzi \& Venturini, 1994).

Subsidies for innovative activities may not be neglected in this framework. There are government subsidies to support SMEs specifically; eg, by applying support criteria that are limited to SMEs. European policy regards SMEs as crucial for the economic welfare of the European U nion and has thus given them priority in the "E uropean Growth Initiative", which provides one billion ECU in the framework of the structural funds in favour of SMEs over the period of 1994-1999. This factor is of special importance because, according to BehrensRamberg (1985), especially tax regulations, the possibilities of getting bank loans, as well as getting investors are disadvantageous for SMEs.

Empirical data on possible relationships between company size and innovativeness are very limited and arrive at contradictory conclusions, which may be due to differences in the measurement of innovativeness (Penzkofer \& Schmalholz, 1994) and/or of size, eg, employment or assets (Scherer, 1984).

By looking at different sets of data, Scherer (1984) found that the inventive output of firms was positively related to firm sales, yet at a less than proportional rate, concluding that the Schumpeter-hypothesis could not be supported. Rothwell and Dodgson (1994) report some empirical findings on the distribution of share of innovations by company size. The Science Policy Research Unit's innovation database for Great Britain showed a growing share of the number of SME innovations, whereas companies with more than 1000 employees were losing. In areas with high capital and $R \& D$ requirements as well as high entry costs, the share of small firms was low. They also report on a study by Acs and Audretsch (1991) using US data of the Small Business Administration's listings, which shows that the innovation rate in SMEs was higher than in large companies. This indicates that small firms do have an advantage in highly innovative industries where the use of skilled labour was relatively important. Rothwell and Dodgson also found that the innovation efficiency of SMEs is much higher. Results of the US National Science Foundation (1987) support this view. However, the contribution of SMEs to innovation varies considerably between sectors. In highly innovative industries, where the use of skilled labour is relatively important, small firms have innovation advantages.

Penzkofer and Schmalholz (1994) looked at innovativeness and company size in various industry sectors in Germany. One result was that there is a clearly positive relationship between company size, concentration and degree of innovation. They claim that these differences are due to the fact that innovativeness by most other authors had been measured in a different way, ie, by using expenses 
on $R \& D, R \& D$ staff and patents as indicators for innovativeness rather than actual innovations. Their empirical data is based on an innovation index that differentiates between product and/or process innovation.

Christensen and Kristensen (1994) made similar observations in an analysis across sectors, which is differentiating between product and process innovations. The companies they considered large (more than 399 employees) where by far more innovative; especially as far as process innovations go.

A common point in most of these findings is that there are significant differences between different industries. Scherer (1984) concludes that, in most industries, size appears to be neither stimulate nor retard innovativeness. The measurement of innovativeness by the output of patents and the analysis across industries opens much room for interpretation. Patents only account for a proportion of all innovations, because in many cases the innovation consists of a change in either construction or design. This seems to be even more true for the food sector where this discrepancy may be expected to be significant due to the rather low degree of innovativeness of most innovations.

Not only is there a difference in the size/innovativeness relationship between industries, but also between different periods of time. Rothwell and Dodgson (1994) claim that dynamic complementarity may exist between large and small firms; eg, in new technology-based sectors like biotechnology, where (independent) new technology-based firms play an important role in a large firm's technological change activities. Whereas these changes occur in the long run, there is also a difference between different stages of the innovative process. Oppenländer (1986) suggested splitting up the innovation process into three stages, namely invention, innovation and diffusion of new technologies. Leder (1989) recommended distinguishing solely between (1) invention and development and (2) market introduction and diffusion, arguing that even this might cause problems because of interferences between these stages due to corrections that have to be made in the turn of the innovation process. So these two stages will be used in the following.

Stage 1, invention and development: while the share of investments in R\&D of SMEs in comparison to those of the economy as a whole is rather small, their innovativeness is not. Their ratio of $R \& D$ activity to total turnover is significantly higher than in the case of large companies, as Rothwell and Dodgson (1994) and Scherer (1984) have pointed out. This is partly caused by a lower degree of functional specialisation in small firms with a higher proportion of innovative activities occurring outside of what is formally defined as $R \& D$. This circumstance is also referred to with ascribing an organic organisational form to these companies.

Considering the characteristics of the food industry, $R \& D$ might not be as crucial for innovation as it is in other industries. Due to the incremental nature of innovation, the market opportunity for line extensions and vertical product differentiation, and the existence of redundant technology, it should be expected that in the food industry innovative activity is less dependent on R\&D expenditures than in other industries (Galizzi \& Venturini, 1994). This indicates that this commonly important hindrance for the innovativeness of SMEs may be regarded as far less important when looking at the food industry. 
Product development in SMEs is carried out more rapidly because competition and pressure on production forces them to convert inventions and devel opments as quickly as possible into marketable products. Instead large companies tend to apply their inventions for patents without looking closely at the possibilities of economic use in the first place (Oppenländer, 1986)

Stage 2, market introduction and diffusion: in introducing innovations to the market, the possibilities of SMEs are comparatively limited. When it comes to distributing the product on a large scale, various problems for SMEs show up, like a lack of financial means, insufficient information on relevant markets, a limited distribution system and a weak market position compared to large companies (unless the innovation opens a market niche).

These weaknesses are quite obvious and signify that imitations are very likely. Consequently in the food sector - despite the lower costs/risk associated with developing new products - the risk concerning investment in diffusion is comparatively high. For large companies, and especially for multinational enterprises, normal market barriers do not present a considerable obstacle. Within their diversification strategy and due to their risk capital and managerial capacities, they may become very potent competitors for SMEs (Hambüchen, 1988).

Innovation and vertical co-operation

The size of the company may actually not be a well-defined variable. By linking other actors in the value chain closer to itself than pure market transactions would allow, a company may extend the range of skills it has command over without formal growth. The arguments about the relationship between the size of a company and its innovativeness are therefore partly modified when possible forms of vertical co-operation are taken into account. To study this phenomenon, it is necessary to look at literature not only on the effects of vertical integration, which is well-analysed, but al so vertical co-operation. We do this on the assumption that some of the effects of vertical integration can be, possibly to a lesser extent, achieved by vertical co-operation as well.

Vertical co-operation is widespread and has been subject to considerable theoretical and empirical investigation (eg, Buzzell, 1983; Etgar, 1976). Four theoretical approaches have been prevalent: a) transaction cost theory (Dwyer \& Oh, 1988; Williamson, 1971, 1985) argues that the boundaries between organisations are determined in such a way that the sum of production and transaction costs is minimised; with production costs constant, increasing transaction costs favour increasing degrees of vertical co-operation or integration, b) the political economy approach to distribution channels (Achrol, Reve \& Stern, 1983; Arndt, 1983; Stern \& Reve, 1980), stressing the importance of both political and economic structures and processes in vertical relationships with pure market interactions as a special and extreme case, c) network theory (Håkansson, 1987), emphasising the structural interdependence of actors on (mainly) industrial markets, and d) theories on strategy and competitive posture, proposing a contingency approach to how market conditions and vertical integration strategies interact to determine competitive position in the market (Day \& Klein, 1987; Harrigan, 1983, 1986). Transaction cost theory has developed the clearest hypo- 
theses on the determinants of vertical co-operation, namely the existence (or degree) of uncertainty and firm-specific assets, and on its effects, namely the reduction of transaction costs. Effects on innovation have not been a prime interest; however, a number of possible effects can be derived and discussed. These refer to the generation of market intel ligence, the devel opment of production competences, and the development of market responsiveness.

Vertical co-operation/integration is acknowledged to change the informational structure in the channel, with possible effects on the generation of market intelligence: it encourages downstream channel members to share their market knowledge with upstream members, and it facilitates the transfer of information by mechanisms like establishment of common frames of reference, etc. (Etgar, 1976). This phenomenon is well-established in the product development literature, going back to the famous studies of von Hippel (1976), showing that, in high technology industries, successful product development is often carried out in dose co-operation between a producer and a user, where the innovation is actually mostly invented, prototyped and field-tested by the user, and the producer only contributes product engineering work. These results are not easily transferred to the food industry, however, where products are usually less complex and product development therefore simpler. Co-operation between food producers and retailers in product development is discussed widely among food producers, but some empirical research shows that retailers are less than enthusiastic about the idea (Grunert, Hartvig Larsen, Madsen \& Baadsgaard, in press), and that retailer interest in this type of co-operation is restricted to retailers with a dear positioning strategy and a strong emphasis on own labels (Dawson \& Shaw, 1989).

Vertical co-operation and especially integration may also impede the generation of market intelligence. Downstream channel members who are not part of the co-operation may become motivated to withhold market knowledge from the producer, who is now regarded not only as a supplier, but also as a competitor (Lundgren, 1990). The choice of co-operation partners then becomes a crucial issue. Anticipating such problems, vertical co-operation may not come about in the first place. If there are many producers and few users, mostly the producers would profit from co-operation, and users may be less motivated to enter such co-operation, which may explain the reluctance of large retail chains to enter cooperation on product development with food producers.

Product (and, to an even larger extent, process) innovation is related to the production competences of the firm. A company may not own and/or not wish to devel op all competences needed to fulfil customer demands, or, put another way, may not be able/not willing to stand for the whole quality function deployment process as depicted in a House of Quality (Kristensen \& Holmen, 1994). Buying such competences by way of market transactions may result in very risky transactions in the context of innovation, which usually implies the exchange of information about skills and resources, future strategies, bottlenecks and inefficiencies in current production approaches, cost estimates, and the like (Globerman, 1980). In such risky transactions, it will be difficult to safeguard against potential conflicts by specifying all kinds of contingencies in a contract. This, together with property rights considerations in the context of product development (Plichta, 1994), may then argue for forms of vertical co-operation in order to develop the necessary portfolio of competences (Armour \& Teece, 1980). More complex innovation processes may therefore provide incentives for 
stronger vertical co-operation, or, put the other way round, stronger forms of vertical co-operation may facilitate more complex innovation processes.

Especially backward vertical co-operation is interesting in the food sector, because in general the competences developed in primary production are not easily imitated by competitors, and can thus contribute to a sustained competitive advantage (Barney, 1991). However, the form of vertical co-operation may have considerable impact on the degree and kind of innovativeness. In the case of co-operatives, it has been argued (Søgaard, 1994) that the political economy of co-operatives discourages innovations which imply differentiation in primary production, whereas they may encourage innovations which aim at a general lift of the quality level of the primary product.

As with the effects of vertical co-operation on the generation of market intelligence, the inflexibility created by committing to one or few partners may have detrimental effects on the development of production competences as well. The existence of firm-specific assets important for the development of production competences, which encourages vertical co-operation with the company possessing the asset, becomes a disadvantage as soon as the asset looses its value, for example due to the introduction of a superior technology (Balakrishnan \& Wernerfelt, 1986). A food producer engaged in backward vertical co-operation may, for example, be stuck with a supplier adhering to traditional production methods, while competing producers without such co-operation respond to a changed market situation and turn to suppliers competent in production taking care of environmental and animal welfare issues.

The combination of improved market intelligence and improved production competences enables improved market responsiveness in the innovation process. But even holding market intelligence generated and production competences constant, varying degrees of vertical co-operation can have an impact on the resulting degree of market responsiveness in innovation. Possible positive effects relate to the increased demands on cross-functional communication which a higher degree of vertical co-operation may require: It has been argued that vertical co-operation improves cross-functional communication abilities, because it requires adequate co-ordination of marketing and technical functions (Buzzell, 1983). Possible negative effects relate to the increased amount of bureaucracy in large vertical systems and have been discussed mainly in connection with large retail chains (Arndt \& Reve, 1979), whose emphasis on price instead of differentiation may inhibit upstream innovation activities when producers fear that new products will after all not be of interest to their main customer.

Empirical evidence is mostly in the form of case studies, and the few quantitative studies that have been carried out are either cross-industry or refer to high technology industries. An analysis based on PIMS data (Buzzell, 1983) has shown that higher degrees of vertical integration (not co-operation) lead to higher degrees of innovation as measured by percentage of sales accounted for by new products. This holds regardless of whether markets are mature or growing, whether technology is changing or not, whether the company has a strong competitive position or not. Positive relationships between vertical cooperation and innovativeness have also been shown in the telecommunications industry (Globerman, 1980), and in the petroleum industry (Armour \& Teece, 1980). Balakrishnan and Wernerfelt (1986) have in a cross-industry study 
tested and confirmed the hypothesis that industries with a high level of technological change (and therefore a high risk of technological obsolescence) have lower degrees of vertical integration.

There are no quantitative studies dealing explicitly with the food industry. A few case studies (Grunert, Hartvig Larsen, Madsen \& Baadsgaard, in press; Kristensen \& Holmen, 1994) have looked at vertical co-operation in the food industry, emphasising how more complex products and a stronger emphasis on credence qualities lead to stronger forms of vertical co-operation.

Vertical co-operation and company size

Growing vertical co-operation might be offering more possibilities for innovation in SMEs. They are gaining importance in intra-industrial labour division, because they are highly adaptive and more flexible. The introduction of quality certification systems may lead to advantages for SMEs: the product development process may become more systematic, process-oriented qualities (credence characteristics of products) are easier to be documented, and this documentation is more trustworthy if it is realised at a company-wide level, which seems to be easier for SMEs.

Vertical co-operation may also be a means of increasing the degree of market orientation of SMEs. While it is not clear that there is actually a difference as far as the degree of market orientation is concerned, there seems to be at least different methods of collecting information. While SMEs usually don't have the expertise and capacities to do extensive market research, they may use different, less systematic techniques of market information. A study of food SMEs in Denmark has actually shown that to a very large degree they rely on direct interaction with their immediate customers to obtain market intelligence (Harmsen, 1994).

Also the $R \& D$ aspect of innovation can be mediated by vertical co-operation. For SMEs, supply with know-how plays an important role. Lack of information is a major obstacle for SMEs. Apart from technical information like technical standards, norms, etc., they also lack information on legal regulations and on possibilities of financing their projects (Staudt, Bock \& Mühlemeyer, 1992). Even though there is an increasing supply of public consulting and transfer institutions, SMEs hesitate in making use of these possibilities. Rather they rely on personal contacts, information from their customers, from other producers and from competitors (Staudt, Bock \& Mühlemeyer, 1992).

\section{Influences on innovation success at the project level}

Product innovations are influenced and formed by a large number of variables on their way from idea to market. The performance of a newly launched product has been shown to be influenced by for example the idea itself, the knowledge base in the company, specific human and financial resources, organisational structures and styles, collaborations between functions, information about customer preferences, launch activities, as well as market characteristics like customer preferences, and competitive patterns. 
A large body of empirical research can be identified that during the last decades has focused on identifying the success factors of product innovation (for more comprehensive summaries of the research area see, eg, Craig \& Hart, 1992; Harmsen, 1992; Hauschildt, 1993; Schewe, 1991). What these studies have in common is the underlying assumption that a number of identifiable factors influence or determine new product performance as well as an ultimate aim of normative prescription regarding product innovation activities. The view is thus management oriented, assuming that knowledge about causal relations regarding new product performance can be used to improve future product innovation situations either by prescribing specific activities or identifying noncontrollable factors that can be used as screening criteria at an early stage in the development process.

Methodologically these studies differ widely. Some studies aim at identifying the entire set of success factors including both internal and external factors and both controllable and non-control lable factors. Others focus on one specific issue or success factor and try to determine its influence on project performance. Another aspect is the type of new product under investigation. Various definitions exist of new products and these are employed more or less explicitly in new product studies. The problem is that it seems that some of the success factors differ for different types of new products. The definition or the measurement of success and failure is another problematic aspect, as mentioned earlier in this paper. Both qualitative and quantitative approaches have been used, with qualitative approaches primarily being used for explorative case studies or longer-term studies of specific change processes (Barclay, 1992; Workman, 1993) and quantitative approaches being used for confirmatory or correlation studies. Populations chosen also differ widely. Examples of populations include companies in specific industries (Nyström \& Edvardsson, 1982; Sneep, 1994), cross-sectional studies (Cooper, 1979, 1990) or studies with a number of companies or industries that share certain characteristics, eg, innovative versus non-innovative (J ohne, 1984), high-tech versus non-high-tech (Karakaya \& Kobu, 1994). Representative studies are rare, and no studies have focused explicitly on the food industry.

Despite the methodological fragmentation, there is considerable agreement that the results show quite a clear picture and that the identified success factors are consistent across a large number of studies.

Lilien and Yoon (1989) state that "the findings of these studies are often similar and consistent" and Cooper (1990) concludes that "the results remain remarkably consistent across studies, regardless of the study's context". Craig and Hart (1992) point out that "on the whole the findings from the studies, ranging over a period of almost 30 years, are very similar". Even though the list of factors influencing new product performance is long, they can be condensed to a number of overall success factors or main themes of new product success. Barclay (1992) identifies the following overall success factors, under which he groups specific results: an open minded and professional management, a good market knowledge and strategy, a unique and superior product that meets customer wants and needs, good communication and co-ordination, and finally proficiency in technological activities. Craig and Hart (1992) come up with a number of themes upon an examination of previous studies: Management, process, company characteristics, people, strategy, and information. 
In this paper, the success factors have been summarised into only three main categories, namely success factors related to product development strategy, market focus, and organisation of product development.

\section{Product devel opment strategy}

A number of the identified success factors, regarding top management involvement and longer term considerations, can be classified as factors concerning product development strategies. An example of this is setting a clear strategy resulting in a focused approach to product development, and strategically recognising the importance of product development - resulting in a supportive climate for product development. More specifically, studies have shown that there are more successful projects where (Cooper \& Kleinschmidt, 1987; Dwyer \& Mellor, 1991; J ohne, 1985; J ohne \& Snelson, 1990; Nyström \& Edvardsson, 1982; Rothwell, 1977):

- an explicit product development strategy exists that defines the types of products to be developed,

- the product development strategy is part of the overall strategy of the company and where the specific strategy is close to existing strengths or activities,

- the product development strategy takes market-related and technological considerations equally into account,

- top management motivates the understanding of the need of new product development,

- top management actively supports the development teams.

Market focus

Regarding market orientation, practically all studies identify critical factors. In short, the emphasis on market orientation builds on an assumption that the success of a new product is determined in the market by the customers' perception of the new product. It is therefore crucial to build the understanding of the customers' needs and wants into the process in order to improve the chances of success.

A number of studies identify market orientation factors at a very aggregate level, leaving little normative guidance. Examples include: attention to marketing, proficiency in marketing, marketing activities, launch activities, and understanding customer or market needs (Cooper, 1979, 1980; Maidique \& Zirger, 1984; Rothwell, 1977). More specific success factors which can be grouped under the label 'market focus' are the degree of product superiority (identified from the customers point of view), the amount/frequency of contact with the market/ 
customers during development, the degree of up-front marketing, representation of the marketing function in the development process, the amount of market/competitor knowledge, the use of advanced market research techniques, test-marketing, and prototype testing with customers (Barclay, 1992; Cooper, 1979, 1980, 1985, 1990; J ohne \& Snelson, 1990; Rothwell, 1992).

While market-oriented product development persistently emerges as a success factor, the normative implications regarding this group of success factors are rather weak. The existing normative literature regarding market-related factors is further mostly concerned with product development for consumer markets, where market research techniques and market testing methods are quite advanced, whereas normative implications regarding industrial products are almost non-existent.

\section{Organisation of product development}

Two different kinds of factors can be found in the category 'organisation'. First, several specific organisational arrangements, like, eg, cross-functional teamwork or the existence of a project leader, have been shown to correlate with success. Secondly, a number of empirically identified new product success determinants related to, eg, the new product itself or market factors, can be dealt with through implementing organisational tools like project screening systems. In other words, the success factors identified in this category cover both independent factors and activities, methods or organisational arrangements that support success factors found in the other categories.

Normative advice on the organisation of new product development activities shows a great degree of agreement across earlier studies, especially on the identification of the most appropriate organisational structures and management support systems for different kinds of development activities, while results concerning more 'soft' factors like management style, values and group communication are more vague. Within this area specifically the following factors correlate with success (Barczak \& Wilemon, 1991; Cooper 1979, 1986, 1990; J ohne, 1985; J ohne \& Snelson, 1990; Kennard, 1991; Roberts, 1977; Souder, 1988):

- co-operation between/co-ordination of R\&D and marketing,

- the use of temporary multi-functional groups (as opposed to sequential processes with the involvement of the different functional departments at different times),

- clear goal setting.

- a participative management style; the project manager defines clear goals and takes time to solve conflicts,

- loose structuring in the initiating phases (idea generation, screening, concept development and concept test, 
- product development as a learning process,

- more formalisation in the implementation phases (eg, formalised development process, standardised control procedures),

- emphasis on up-front activities (initial screening, initial market assessment, initial technical assessment),

- formalised product development process (with a description of activities and control procedures),

- emphasis on accomplishing all phases and activities in the process.

Summing up, the success factors at the strategic level point to the importance of a purposeful and goal-oriented approach to product development and specifically underline the importance of balancing technological and market-related aspects as well as focusing on synergy with existing activities. The success factors under the label market focus can be interpreted both as a number of specific activities associated with greater success (eg, up-front marketing activities) and as a philosophy guiding these specific activities. Finally, the factors related to organising product development can be interpreted both as a means to an end (eg, securing that up-front marketing activities are taking place by institutionalising this activity in a formalised product development manual) and as a number of factors directly influencing the outcome of product development projects.

It should be noted that, despite the consistency of results, some areas are unresearched and need further attention in the future, including the relationship between different levels of analysis and success, the interrelatedness of success factors, the capabilities behind some of the identified specific activities and organisational styles, as well as the possibility of implementing previously discovered success factors.

\section{ISSUES IN THE ANALYSIS OF INNOVATION IN THE FOOD SECTOR}

This paper has discussed a number of aspects of innovation in companies. More specifically, it has looked at how R\&D and market orientation as major input to the innovation process are related to business performance, and at a number of factors that are related to innovation success and business performance at various levels of analysis. The basic framework was depicted in figure 1.

In this paper, a product innovation was defined as something which is new to the consumer, the distributor, and/or the producer. An innovation can therefore be caused by any changes in the marketing parameters, not only by changes in the physical product. A process innovation was defined as investments enabling product innovations. Innovations can be more or less successful, as measured by market acceptance of fulfilment of company goals. Companies can differ in their degree of innovativeness, depending on the number and success of their innovations. 
It has been shown that there are two major views on innovation. In one view, innovation is closely linked to technological change and to research and devel opment (R\&D) activities: a view prevailing in the industrial economics literature. In the other view, mainly taken in the marketing literature, innovation is regarded as the detection and fulfilment of unfilled needs and wants of potential customers, presupposing a market orientation of the innovative company.

The relationship of both research and development and market orientation has been the object of some theoretical and empirical scrutiny. However, there is no clear-cut evidence on the relationship between the extent of R\&D activities and business. There is some empirical evidence that a higher degree of market orientation leads to improved business performance. However, it has been argued in this paper that these relationships actually mask the real factors at work, especially when viewed from an innovation perspective. Neither R\&D nor market orientation influence business performance directly. However, interactively they have major bearings on the innovation process and on the market acceptance of the resulting innovations, which again will have an impact on business performance.

The innovation process itself can be analysed at the supra-company, at the company and at the project levels. At the supra-company level, the innovation process is affected by how the company is embedded in networks, clusters, and chains. At the company level, the size of the company may have an impact on its innovativeness, but the relationship is not clear, arguments being raised for a higher degree of innovativeness of both small and large companies. Vertical cooperation between companies may improve innovativeness in three ways: downstream vertical co-operation can facilitate the generation of market intelligence, upstream vertical co-operation may facilitate the acquisition of production competences necessary for innovation, and the communicational requirements of vertical co-operation may facilitate market responsiveness. Research on the determinants of success at the project level has identified three groups of factors: the existence of a clearly defined new product development strategy, market focus in the product development process, and the organisation of the product development process, especially a certain degree of formalisation.

Almost all the research covered in this paper has not dealt explicitly with the food industry. Empirical studies mentioned were either cross-industry or dealt with other, typically more high technology industries. Still, the theories and research presented are useful sources for factors to look at, also in the food industry. However, specific features of food products and the food industry may bring some theories and research questions into the for efront. Typical characteristics of food products, such as their nutritional benefits and perishability, have consequences for the focus of product innovation. The quality of agricultural input is very important for food products, which makes vertical relations with farmers and sometimes also with breeding companies important for the innovation process. Also, doing business with large food chains has its impact on innovation in the food industry.

The following questions would be especially relevant to look at in empirical research dealing with innovation in the food industry: 
To what extent is innovation in food companies based on the identification of market opportunities, how is this market intelligence generated, and how is it channelled into the innovation process?

To what extent is innovation in food companies based on $R \& D$, who or what triggers the $R \& D$ process, and how is it related to product innovation?

How are R\&D, market intelligence, and the company's other competences, especially in terms of production, combined in the innovation process?

Which competences in terms of $R \& D$, market orientation, and production are devel oped within the food company, and which competences are devel oped in cooperation with other actors in the food chain?

What is the role of networks and clusters, ie, the primary environment of the food company, in its innovation process?

How do larger and smaller food companies differ in their innovation processes?

How is the innovation process organised, and how does this compare to the criteria of clear product development strategy, market focus, and formal organisation of the product development process?

How is innovativeness related to business performance? 


\section{REFERENCES}

Abell, D. F. \& Hammond, J. S. (1979). Strategic market planning. Englewood Cliffs, NJ : Prentice-Hall.

Abernathy, W. J \& \& Utterback, J . M. (1978). Patterns of industrial innovation. Technology Review, 80, 40-47.

Achrol, R. S. (1991). Evolution of the marketing organization: New forms for turbulent environments. J ournal of Marketing, 55(4), 77-93.

Achrol, R. S., Reve, T. \& Stern, L. W. (1983). The environment of marketing channels dyads: A framework for comparative analysis. J ournal of Marketing, 47(4), 55-67.

Acs, Z. J. \& Audretsch, D. B. (1991). Innovation and firm size in manufacturing. Technovation, 7, 197-210.

Ansoff, I. H. (1965). Corporate strategy. New York: McGraw Hill.

Armour, H. O. \& Teece, D. J . (1980). Vertical integration and technological innovation. The Review of Economics and Statistics, 62(3), 470-474.

Arndt, J. (1983). The political economy paradigm: Foundation for theory building in marketing. J ournal of Marketing, 47(4), 44-54.

Arndt, J . \& Reve, T. (1979). Innovativeness in vertical marketing systems. In: G. Fisk, R. W. Nason \& P. D. White (Eds.), Macromarketing: Evolution of thought, pp. 223-238. Boulder, CO: University of Colorado.

Balakrishnan, S. \& Wernerfelt, B. (1986). Technical change, competition and vertical integration. Strategic Management J ournal, 7, 347-359.

Barday, I. (1992). The new product development process: Past evidence and future practical application, Part 1. R\&D Management, 22, 255-263.

Barczak, G. \& Wilemon, D. (1991). Leading the way. Product \& Process Innovation, 1(6), 21-26.

Barney, J. B. (1991). Firm resources and sustained competitive advantages. J ournal of Management, 17(1), 99-120.

Behrens-Ramberg, W. (1985). Steuerliche Anreize be innovativen Investitionen kleiner und mittlerer Industrieunternehmen unter vergleichender Berücksichtigung nichtsteuerlicher Hilfen. Stuttgart: Poeschel.

Biemans, W. G. (1992). Managing innovation within networks. London: Routledge.

Booz, Allen \& Hamilton (1982). New products management for the 1980s. New York: Booz, Allen \& Hamilton.

Buzzell, R. D. (1983). Is vertical integration profitable? Harvard Business Review, 61(1), 92-102.

Carlsson, B. (1994). Technol ogical systems and economic performance. In: M. Dodgson \& R. Rothwell (E ds.), The handbook of industrial innovation, pp. 13-24. Aldershot: Edward Elgar.

Christensen, L. \& Kristensen, A. (1994). Innovation i danske industrivirksomheder. Copenhagen: Erhvervsfremme Styrelsen.

Clark, P. \& Staunton, N. (1989). Innovation in technology and organisation. London: Routledge. 
Commission of the European Communities (1992). Dable Report 1: Synopsis of European enterprises 1992. Brussels: Commission of the European Communities.

Cooke, P. \& Morgan, K. (1994). The creative milieu: a regional perspective on innovation. In: M. Dodgson \& R. Rothwell (Eds.), The handbook of industrial innovation, pp. 25-32. Aldershot: Edward Elgar.

Cooper, R. G. (1979). The dimensions of industrial new product success and failure. J ournal of Marketing, 43(3), 93-103.

Cooper, R. G. (1980). How to identify potential new product winners. Research Management, (September), 10-19.

Cooper, R. G. (1984). New product strategies. What distinguishes top performers? J ournal of Product Innovation Management, 1, 151-164.

Cooper, R. G. (1985). Selecting winning new product projects. J ournal of Product Innovation Management, 2, 34-44.

Cooper, R. G. (1990). New products: What distinguishes the winners? Research \& Technology Management, 10(6), 27-31.

Cooper, R. G. \& Kleinschmidt, E. J . (1987). New products: What separates winners from loser? J ournal of Product Innovation Management, 4, 169-184.

Cooper, R. G. \& Kleinschmidt, E. J. (1987). Success factors in product innovation. Industrial Marketing Management, 16, 215-223.

Cozijnsen, A. J . (1989). Het innovati evermogen van politieorgani saties. Deventer: Kluwer Bedrijfswetenschappen.

Craig, A. \& Hart, S. (1992). Dimensions of success in new product development. In: K. G. Grunert \& D. Fuglede (Eds.), Marketing for Europe - Marketing for the Future, EMAC Conference Procedings, pp. 173-195. Aarhus: The Aarhus School of Business.

Craig, A. \& Hart, S. (1992). Where to now in new product development? European J ournal of Marketing, 26(11), 1-50.

Davies, S. (1988). Technical change, productivity and market structure. In S. Davies \& B. Lyons (Eds.), Economics of industrial organisation, pp. 192-246. London: Longman.

Dawson, J . A. \& Shaw, S. A. (1989). The move to administered vertical marketing systems by British retailers. European J ournal of Marketing, 23(7), 42-52.

Day, A. (1994). The capabilities of market-driven organizations. J ournal of Marketing, 58, 37-52.

Day, G. S. \& Klein, S. (1987). Cooperative behavior in vertical markets: The influence of transaction costs and competitive strategies. In: M. J. Houston (Ed.), Review of marketing, pp. 39-66. Minnesota: American Marketing Association.

Day, G. S. \& Wensley, R. (1988). Assessing advantage: A framework for diagnosing competitive superiority. J ournal of Marketing 52(2), 1-20.

Dreher, A. (1994). Marketing orientation: How to grasp the phenomenon. In: M. J . Baker (Ed.), Perspectives on marketing management, vol. 4, pp. 149-170. Chichester: Wiley.

Dwyer, F. R. \& Oh, S. (1988). A transaction cost perspective on vertical contractual structure and interchannel competitive strategies. J ournal of Marketing, 52, 21-34.

Dwyer, L. \& Mellor, R. (1991). Organizational environment, new product process activities, and project outcomes. J ournal of Product Innovation Management, 8, 39-49. 
Etgar, M. (1976). Effects of administrative control on efficiency of vertical marketing systems. J ournal of Marketing Research, 13, 12-24.

Fairtlough, G. (1994). Innovation and organization. In M. Dodgson \& R. Rothwell (Eds.), The handbook of industrial innovation, pp. 325-336. Aldershot: Edward Elgar.

Frøslev Christensen, J., Karnøe, P. \& Norvig Larsen, J. (1990). Projekt dynamisk specialisering. Copenhagen: Institut for Erhvervs- og samfundsforskning.

Galbraith, K. (1952). American capitalism: The concept of countervailing power. Boston: Houghton Mifflin.

Galizzi, G. \& Venturini, L. (1994). Product innovations in the food industry: Nature, characteristics and performances. In: G. Galizzi et al. (Eds.), $4^{\circ}$ Convegno Internazionale, Economia e Politica del'Innovazione II Caso dell'Industria Alimentare Piacenca: Universitá Cattolica del Sacro Cuore.

Geschka, H. (1990). Innovationsmanagement. In: C. Pfohl (Ed.), Betriebswirtschaftslehre der Mittel- und Kleinbetriebe: Grössenspezifische Probleme und Möglichkeiten zu ihrer Lösung, pp. 157-178. Berlin: Erich Schmidt.

Globerman, S. (1980). Markets, hierarchies and innovation. J ournal of Economic I ssues, 14, 977-998.

Griffin, A. \& Page A. L. (1993). An interim report on measuring product development success and failure. J ournal of Product Innovation Management, 10(4) 291-308.

Grunert, K. G., Hartvig Larsen, H., Madsen, T. K. \& Baadsgaard, A. (in press). Market orientation in food and agriculture. Boston: Kluwer.

Gupta, A. K., Raj, S. P., \& Wilemon, D. (1986), A model for studying R\&D-marketing interface in the product innovation process. J ournal of Marketing, 50, 7-17.

Håkansson, H. (1987). Industrial technological development: A network approach. London: Croom Helm.

Hambüchen, T. E. (1988). Innovationen als produktpolitische Maßnahme in der Milchwirtschaft der BRD. Kiel: Wissenschaftsverlag Vauk.

Harmsen, H. (1992). Determinanter for produktinnovationssucces. MAPP working paper no. 5. Aarhus: The Aarhus School of Business.

Harmsen, H. (1994). Product development practice in medium-sized food processing companies: Increasing the level of market orientation. In: Proceedings of the EIASM Conference on N ew Approaches to Devel opment and Engineering. Gothenburg: University of Gothenburg.

Harmsen, H. (1994). Tendencies in product development in Danish food companies. Report of a qual itative analysis. MAPP working paper no 17. Aarhus: The Aarhus School of Business.

Harrigan, K. R. (1983). Strategies for vertical integration. Lexington, MA: Lexington Books.

Harrigan, K. R. (1986). Matching vertical integration strategies to competitive conditions. Strategic Management J ournal, 7, 535-555.

Hauschildt, J . (1993). Innovationsmanagement. München: Vahlen.

Henderson, R. \& Clark, K. (1990), Architectural innovation: the reconfiguration of existing product technol ogies and the failure of established firms. AdministrativeScience Quarterly, 35, 317-341. 
Hughes, D. (Ed) (1994). Breaking with tradition: Building partnerships and alliances in the European food industry. London: Wye College Press.

J aworski, B. J . \& Kohli, A. K. (1993). Market orientation: Antecedents and consequences. J ournal of Marketing, 57(3), 53-70.

J ohne, A. \& Snelson, P. (1990). Successful product innovation in UK and US firms. European J ournal of Marketing, 12, 7-21.

J ohne, F. A. (1984). How experienced product innovators organize. J ournal of Product Innovation Management, 1, 210-233.

J ohne, F. A. (1985). Industrial product innovation. London: Croom Helm.

Karakaya, F. \& Kobu, B. (1994). New product development process: An investigation of success and failure in high-technology and non-high-technology firms. J ournal of Business Venturing, 9, 49-66.

Kennard, R. B. (1991). From experience: J apanese product development process. J ournal of Product Innovation Management, 8, 184-189.

Kohli, A. \& Jaworski, B. J. (1990). Market orientation: The construct, research propositions and managerial implications. J ournal of Marketing, 54(2), 1-18.

Kohli, A. K., Jaworski, B. J. \& Kumar, A. (1993). MARKOR: A measure of market orientation. J ournal of Marketing Research, 30 , 467-477.

Kotler, P. (1991). Marketing management - analysis, planning, implementation, and control, 7th ed. London: Prentice Hall.

Kristensen, P. S. (1992). Product development strategy in the Danish agricultural complex: Global interaction with clusters of marketing excellence. The International J ournal of Food and Agribusiness Marketing, 4(3), 107-118.

Kristensen, P. S. \& Holmen, E. (1994). Identification of a supplier network through Qual ity Function Deployment. Paper presented at the 10th IMP Conference, Groningen, September 30 - October 1, 1994.

Leder, M. (1989). Innovationsmanagement. Zeitschrift für Betriebswirtschaft, 59, 1-54.

Lichtenthal, J . D. \& Wilson, D. T. (1992). Becoming market oriented. J ournal of Business Research, 24, 191-207.

Lilien, G. \&. Yoon, E.(1989). Determinants of new product performance: A strategic reexamination of the empirical literature. IEEE Transactions on Engineering Management, 36(1), 3-11.

Lilienthal, D. E. (1953). Big business: A new era. New York: Harper.

Littler, D. (1994). Marketing and innovation. In: M. Dodgson \& R. Rothwell (Eds.), The handbook of industrial innovation, pp. 293-300. Aldershot: Edward Elgar.

Lundgren, K. (1990). Vertical integration, transaction costs and 'learning by using'. In: M. Oaki, B. Gustafsson \& O. E. Williamson (Eds.), The firm as a nexus of treaties, pp. 112132. London: Sage.

Madsen, T. K. (in press). The structure and behaviour of some Danish food companies. MAPP working paper. Aarhus: The Aarhus School of Business.

Mahajan, V., Muller, E., \& Bass, F. M. (1993). New product diffusion models. In: J. Eliashberg \& G. L. Lilien (Eds.), Marketing handbooks in operations research and management science, vol. 5, pp. 349-402. Amsterdam: North Holland. 
Maidique, M. \& Zirger, B. (1984). A study of success and failure in product innovation: The case of the U.S. electronics industry. IEEE Transactions on Engineering Management, 31, 192-203.

Mensch, G. (1979). Beobachtungen zum Innovationsverhalten kleiner, mittlerer und mittelgroßer Unternehmen. Zeitschrift für Betriebswirtschaft, 49, 72-78.

Miles, R. E., \& Snow, C.C. (1978). Organizational strategy, structure, and process. New York: McGraw-Hill.

Narver, J. C. \& Slater, S. F. (1990). The effect of a market orientation on business profitability. J ournal of Marketing, 54(4), 20-35.

National Science Foundation (1987). Science and technology indicators. Washington, DC: Avery.

Nijkamp, W. G. (1993). New product macroflow models. Groningen: Van Denderen.

Nyström, H. \& Edvardsson, B. (1982). Product innovation in food processing - a Swedish survey. R \& D Management, 12(2), 67-72.

Oppenländer, K. H. (1986). Zur Innovationskraft kleiner und mittlerer Unternehmen. I fo-Studien, 32, 131-142.

Pavitt, K. (1986). Technology, innovation, and strategic management. In: J. McGee \& H. Thomas (Eds.), Strategic management research - a European perspective, pp. 171-190. New York: Wiley.

Penzkofer, H. \& Schmalholz, H. (1994). Der Zusammenhang zwischen Marktstruktur, Innovationsverhalten und dynamischem Wettbewerb. In: I fo-Studien zur Innovationsforschung. Munich: ifo.

Plichta, K. (1994). Technological development in the fruit and vegetable industry: A property rights perspective MAPP working paper no. 23. Aarhus: The Aarhus School of Business.

Porter, M. E. (1990). The competitiveness of nations. New York: Free Press.

Powell, W. W. (1990). Neither market nor hierarchy: network forms of organizations. In B. Staw \& L. L. Cunnings (Eds.), Research in organizational behavior, Greenwich, CO: $J$ ai Press.

Roberts, E. B. (1977). Generating effective corporate innovation. Technol ogy Review, 79, 27-33.

Rothwell, R. (1977). The characteristics of successful innovators and technically progressive firms. R \& D Management, 7, 191-206.

Rothwell, R. (1985). Venture capital, small firms and public policy in the UK. Research Policy, 1, 51-64

Rothwell, R. (1992). Successful industrial innovation: Critical factors for the 1990s. R\&D Management, 22, 221-239.

Rothwell, R. (1994). Industrial innovation: success, strategy, trends. In: M. Dodgson \& R. Rothwell (Eds.), The handbook of industrial innovation, pp. 33-53. Aldershot: Edward Elgar.

Rothwell, R. \& Dodgson, M. (1994). Innovation and size of firm. In: M. Dodgson \& R. Rothwell (Eds.), The handbook of industrial innovation, pp. 310-324. Aldershot: Edward Elgar. 
Rothwell, R. \& Zegfeld, R. (1982). Innovation and the small and medium-sized firm. London: Pinter.

Ruekert, R. W. (1992). Developing a market orientation: An organizational strategy perspective. International J ournal of Research in Marketing, 9, 225-245.

Scherer, F. M. (1984). Innovation and growth. Cambridge, MA: MIT Press.

Scherer, F. M. \& Ross, D. (1990). Industrial market structure and economic performance, 3rd ed. Boston: Houghton Mifflin.

Schewe, G. (1991). Key factors of successful innovation management. Working paper no. 274. Institute for Business Administration, University of Kiel, Germany.

Schumpeter, J . A. (1939). Business cycles: A theoretical, historical and statistical analysis of the capitalist process. New York: McGraw-Hill.

Shaw, B. (1994). U ser/supplier links and innovation. In M. Dodgson \& R. Rothwell (E ds.), The handbook of industrial innovation, pp. 275-284. Aldershot: Edward Elgar.

Shumaker, E. F. (1973). Small is beautiful. London: Blond \& Briggs.

Slater, S. F. \& Narver, J . C. (1994). Does competitive environment moderate the market orientation-performance relationship? J ournal of Marketing, 58, 46-55.

Sneep, A. G. (1994). Innovation management in the Dutch agro/ food industry. Amsterdam: Thesis Publishers.

Søgaard, V. (1994). Farmers, cooperatives, new food products. MAPP monograph. Aarhus: The Aarhus School of Business.

Souder, W. E. (1988). Managing relations between $r \& d$ and marketing in new product development projects. J ournal of Product Innovation Management, 5, 6-19.

Staudt, E, Bock, J . \& Mühlemeyer, P. (1992). Informationsverhalten von innovationsaktiven kleinen und mittleren Unternehmen. Zeitschrift für Betriebswirtschaft, 62, 989-1008.

Stern, L. W. \& Reve, T. (1980). Distribution channels as political economies: A framework for comparative analysis. J ournal of Marketing, 44(3), 52-64.

Sundbo, J. (1994). Tre grundopfattelser i innovationsteorien. Ledelse og Erhvervsøkonomi, 58, 169-180.

Takeuchi, H. \& Nonaka, I. (1986). The new new product development game. Harvard Business Review, 64, 134-146.

Teece, D. J. (1988) Technological change and the nature of the firm. In: G. Dosi, C. Freeman, R. Nelson, G. Silverberg \& L. Soete (Eds.), Technical change and economic theory. London: Pinter.

Tirole, J. (1988) The theory of industrial organization. Cambridge, MA: MIT Press.

Traill, W. B. (Ed.) (1989). Prospects for the European food system. London: Elsevier Applied Science.

Urban, G. L., Hauser, J . R., \& Dholakia, N. (1987). Essentials of new product management. Englewood Cliffs, NJ : Prentice Hall.

Utterback, J . M. (1994). Mastering the dynami cs of innovation. Boston: Harvard Business School Press.

Villard, H. H. (1958). Competition, oligopoly and research. J ournal of Political Economy, $66,483-497$. 
von Hippel, E. (1976). The dominant role of users in the scientfic instrument innovation process. Research Policy, 5, 212-239.

Webster, F. E., J r. (1992). The changing role of marketing in the corporation. J ournal of Marketing, 56(4), 1-17.

Williamson, O. E. (1971). The vertical integration of production: Market failure considerations. American Economic Review, 61 (May), 112-123.

Williamson, O. E. (1985). The economic institutions of capitalism. New York: Free Press.

Workman, J. P. (1993). Marketing's limited role in new product development in one computer systems firm. J ournal of Marketing Research, 30, 405-21.

Yon, B. (1992). Innovation et capital risque: les cas des bi otechnol ogies. Paris: Les editions d'organisation. 


\section{MAPP PUBLICATIONS}

\section{MAPP working papers}

No. 1: Grunert, K. G. \& Baadsgaard, A. Market-based process and product innovation in the food sector: A Danish research programme, J anuary 1992.

No. 2: $\quad$ Thøgersen, J. Fødevareinnovation og emballage - miljøkonsekvenser og forbrugerreaktioner, Marts 1992.

No. 3: Bonke, J. Choice of foods - allocation of time and money, household production and market services, September 1992.

No. 4: $\quad$ Grunert, K. G. \& Ellegaard, C. The concept of key success factors: Theory and method, October 1992.

No. 5: $\quad$ Harmsen, H. Determinanter for produktinnovationssucces, November 1992.

No. 6: $\quad$ Grunert, K. G., Nissen, L. \& Wildenhoff, L. Do Danish food companies analyse their competitors, February 1993.

No. 7: Bech-Larsen, T. Overvejer forbrugerne emballagens funktions- og miljøegenskaber, når de køber fødevarer? Februar 1993.

No. 8: $\quad$ Lassen, J. Food quality and the consumer, March 1993.

No. 9: Bonke, J. Choice of foods - allocation of time and money, household production and market services, PART II, September 1993.

No. 10: Plichta, K. Technol ogical opportunities and paths of development, September 1993.

No. 11: Kvistgaard, M., Plichta, K. \& Rasmussen, O. Den danske brødindustri struktur, teknol ogi, forskningsbehov, Oktober 1993

No. 12: $\quad$ Grunert, K.G., Brunsø, K. \& Bisp, S. Food-related life style: Devel opment of a cross-culturally valid instrument for market surveillance, October 1993

No. 13: Hansen, J. K. \& Sørensen, H. C. The importance of the price for the sale of ecological products, November 1993.

No. 14: Grunert, K. G. \& Grunert, S. C. A comparative analysis of the influence of economic culture on East and West German consumers' subjective product meaning, November 1993.

No. 15: Langhoff, T. N. The internationalization of the firm in an intercultural perspective, November 1993.

No. 16: Grunert, K. G. \& Brunsø, K. Market surveillance for the food industry, November 1993.

No. 17: Harmsen, H. Tendencies in product development in Danish food companies Report of a qualitative analysis, February 1994

No. 18: Martensen, A. A mode for marketing planning for new products, February 1994.

No. 19: Bech, A. C., Engelund, E., J uhl, H. J ., Kristensen, K. \& Poulsen, C. S. QFood - Optimal design of food products, March 1994.

No. 20: Juhl, H. J. A sensory analysis on butter cookies - An application of Generalized Procrustes Analysis, March 1994.

No. 21: Andersen, E. S. The evolution of credence goods: A transaction approach to product specification and quality control, May 1994. 
No. 22: J ensen, N. N., Grunert, K. G, Baadsgaard, A., Gede, M. P. Sales determinants of canned pork products: A world-wide study, J une 1994.

No. 23: $\quad$ Plichta, K. Technological development in the fruit and vegetable industry: A property rights perspective, August 1994.

No. 24: $\quad$ Land, B. Ways of life analysis and food cultures, September 1994.

No. 25: Plichta, K., Rossen, L. \& Skovboe, P. Den danske frugt- og grøntbranche, Struktur, teknol ogi, forskningsbehov, December 1994.

No. 26: Askegaard, S. \& Madsen, T. K. European food cultures: An exploratory analysis of food related preferences and behaviour in European regions, September 1995

No. 27: J uhl, H. J., Poulsen, C. S., Kristensen, K., Bech, A. C. \& Engelund, E. Structuring latent consumer needs using LISREL, October 1995

No. 28: Bech, A. C, J uhl, H. J , Kristensen, K. \& Poulsen, C. S. Sensorisk analyse i relation til marekdsorienteret produktudvikling af fødevarer, Oktober 1995.

No. 30 Thøgersen, J. The demand for environmentally friendly packaging in Germany, November 1995.

No. 34 Grunert, K. G., Grunert, S. C. \& Sørensen, E. Means-end chains and laddering: An inventory of problems and an agenda for research. November 1995

No. 38 Grunert, K. G., Harmsen, H., Meulenberg, M., Kuiper, E., Ottowitz, T., Declerk, F., Traill, B. \& Göransson, G. A framework for analysing innovatin in the food sector. November 1995.

\section{MAPP monographs}

Søgaard, V. Farmers, cooperatives, new food products, May 1994.

\section{MAPP conference papers}

Baadsgaard, A., Gede, M. P., Grunert, K. G. \& J ensen, N. N. Lagged life cycle structures for food products: Their role in global marketing, their determinants, and some problems in their estimation, First International Multidisciplinary Conference on Food Choice, Brussels, J uly 27-30, 1992.

Grunert, K. G. Towards a concept of food-related life style, First International Multidisciplinary Conference on Food Choice, Brussels, J uly 27-30, 1992.

J elsøe, E., Land, B. \& Lassen, J. Understanding consumer perceptions and pri orities with relation to food quality, First International Multidisciplinary Conference on Food Choice, Brussels, J uly 27-30, 1992.

Kristensen, P. S. Global product development interaction between local networks: A study of the Danish food industry. The 8th IMP Conference on Business Networks in an International Context: Recent research developments. Lyon, France, September 3-5, 1992. 
Brunsø, K. Market surveillance systems and food related life style The Sixth Colloquium for Doctoral Students in Marketing, Barcelona, May 23-25, 1993.

Plichta, K. \& Harmsen, H. Studies of key success factors of product devel opment success: A reinterpretation of results, 22nd Annual Conference of the European Marketing Academy, Barcelona, May 23-28, 1993.

Thøgersen, J. Emballagens miljøbelastning. En mål-middelanalyse af forbrugernes problemopfattel se og Iøsningsstrategier, Nordisk Netvärkskonferens: Business Strategy and the Environment, Gothenburg, October 7-8, 1993.

Lassen, J. \& J elsøe, E. Food production, food quality and the consumer. 16th Annual Scientific Meeting, AGEV Working Association for Nutrition Behaviour. Potsdam, October 14-16, 1993.

Grunert, K. G. \& Brunsø, K. Food-related life style: results from a cross-cultural investigation. 16th Annual Scientific Meeting, AGEV Working Association for Nutrition Behaviour. Potsdam, October 14-16, 1993.

Askegaard, S. \& Madsen, T. K. European food cultures: An exploratory analysis of food consumption in European regions. Fourth Symposium on Cross-Cultural Consumer \& Business Studies, Kahuku, Hawaii, December 15-18, 1993.

Harmsen, H. Improving product development practices: An action-research based approach. Meeting the Challenges of New Product Development. Manchester School of Management, May 7-10, 1994.

Sørensen, E. \& Grunert, K. G. Identification of managers' perceived key success factors. The Second International Managerial and Organisational Cognition Workshop. EIASM, Brussels, May 26-27, 1994.

J uhl, H. J., Kristensen, K., Poulsen, C. S. Bech, A. \& Engelund, E. Developing food products in accordance with customer demands. The Second International Product Development Conference on New Approaches to Development and Engineering, EIASM, Gothenburg, May 30-31, 1994.

Harmsen, H. Product development practice in medium-sized food processing companies: Increasing the level of market orientation. The Second International Product Development Conference on New Approaches to Development and Engineering, EIASM, Gothenburg, May 30-31, 1994.

Brunsø, K. \& Grunert, K. G. I dentifying food-related life style segments by a cross-culturally valid scaling device. The IAREP/SABE conference, Rotterdam, J uly 10-13, 1994.

Thøgersen, J. Recycling as moral behaviour. The IAREP/SABE conference, Rotterdam, J uly 10-13, 1994.

Ölander, F. \& Thøgersen, J . Understandning of consumer behaviour as a prerequisite for environmental protection. The 23rd International Congress of Applied Psychology, Madrid, J uly 17-22, 1994.

Andersen, E. S. Innovation and quality standardisation: The evolution of complex industrial systems and complex product designs. International Schumpeter Society Conference, Münster, August 17-20, 1994.

Kristensen, P. S. \& Holmen, E. Identification of a supplier network through Quality Function Deployment. 10th IMP Conference, Groningen, September 30-October 1, 1994.

Brunsø, K. \& Grunert, K. G. Development and testing of a cross-culturally valid instrument: Food-related life style The ACR conference, Boston, October 20-23, 1994.

Askegaard, S. \& Madsen, T. K. Homogeneity and heterogeneousness in European food cultures: An exploratory analysis. 24th EMAC Conference, Paris, May 16-19, 1995. 
Thøgersen, J. German consumers'packaging preferences. A conjoint analysis. 24th EMAC Conference, Paris, May 16-19, 1995.

Bouchet, D. Embarrassment as a key to understanding cultural differences. Basic principles of cultural analysis. The Second Conference on The Cultural Dimension of International Marketing, Odense University, Denmark, May 27-31, 1995.

Grunert, K. G., Sørensen, E., J ohansen, L. B. \& Nielsen, N. A. Analysing food choice from a means-end perspective The ACR European Conference, Copenhagen, Copenhagen Business School, J une 14-17, 1995

J ohansen, L. B. \& Grunert, K. G. Determinants of the consumption of fish and shellfish in Denmark: An application of the Theory of Planned Behaviour. International Seafood Conference: Seafood from producer to consumer, integrated approach to quality, Noordwijkerhout, The Netherland, November 13-15.

Nielsen, N. A., Sørensen, E. \& Grnenrt, K. G. Consumer motives for buying fresh or frozen plaice - a means-end chain approach. International Seafood Conference: Seafood from producer to consumer, integrated approach to quality, Noordwijkerhout, The Netherland, November 13-15.

Bech, A. C., Kristensen, K., J uhl, H. J . \& Poulsen, C. S. Devel opment of farmed smoked ed in accordance with consumer demands. International Seafood Conference: Seafood from producer to consumer, integrated approach to quality, Noordwijkerhout, The Netherland, November 13-15.

\section{MAPP reprints}

Askegaard, S. (1993). A European regional analysis of selected food consumption statements, In: W. F. Van Raaij \& G. J. Bamossy (Eds.). European advances in consumer research, Vol. 1. pp. 410-415. Provo, UT: Association for Consumer Research.

Askegaard, S. \& Ludvigsen, H. H. (in press). European food cultures in a macro and mi cro perspective: I mplications for the marketing of Asian food products: I n: J . Cote \& S. M. Leong (E ds.), Asia-Pacific advances in consumer research, Vol 1. Provo, UT: Association for Consumer Research.

Askegaard, S. \& Madsen, T. K. (1993). Fødevareforbrug - et regionernes Europa? Perspektiver for danske virksomheder. Ledelse og Erhvervsøkonomi, 57 (4), 233-248.

Bech, A. C., Engelund, E., J uhl, H. J ., Kristensen, K. \& Poulsen, C. S. (1993). Optimalt design af fødevarer, Ledelse og Erhvervsøkonomi, 57 (4), 199-211.

Bech-Larsen, T. (1993). Indgår fødevareemballagens funktions- og miljøegenskaber i forbrugernes købsovervejelser? Ledel se og Erhvervsøkonomi , 57 (4), 223-232.

Biemans, W. \& Harmsen, H. (1995). Overcoming the barriers to market-oriented product development. J ournal of Marketing Practice: Applied Marketing Science, 1(2), 7-25.

Bonke, J. (1993). Husholdningernes valg af fødevarer - strategier for rationel adfærd. Ledelse og Erhvervsøkonomi, 57 (4), 249-259.

Bouchet, D. (1995). Tvetydigheden i interkulturel kommunikation. Ledelsei Dag 4(3), 7076.

Bouchet, D. (1995) Marketing and the redefinition of ethnicity. In: J. A. Costa \& G. J . Bamossy (Eds.), Marketing in a multicultural world: Ethnicity, nationalism, and cultural identity. Thousand Oaks, CA: Sage Publications. 
Bouchet, D. (1995). Det pinlige som nøgle til opfattelse af kulturelle forskelle. Ledelse i Dag 17(1), 85-96.

Brunsø, K. \& Grunert, K. G. (1993). Fødevarerelateret livsstil: et instrument til markedsovervågning i fødevareindustrien, Ledelse og Erhvervsøkonomi, 57 (4), 213221.

Brunsø, K.\& Grunert, K. G. (in press). Development and testing of a cross-culturally valid instrument. Food-related life style. In: F. Kardes \& M. Sujan (Eds.), Advances in consumer research, Vol 22. Provo, UT: Assication for Consumer Research.

Godt, J ., Kristensen, K., Poulsen, C. S., J uhl, H. J . \& Bech, A. C. (in press). A consumer study of Danish entire male pigs. Fleischwirtschaft, 75.

Grunert, K. G. (1993). Towards a concept of food-related life style. Appetite 21, 151-155.

Grunert, K. G. (1994). Subjektive Produktbedeutungen: Auf dem Wege zu einem integrativen Ansatz in der Konsumforschung. In: Forschungsgruppe Konsum und Verhalten (Eds.), Konsumentenforschung, pp. 215-226. Munich: Vahlen.

Grunert, K. G. (1995). Konkurrentenanalyse. In: R. Köhler, B. Tietz \& J. Zentes (Eds.). Handwörterbuch des Marketing. pp 1226-1234. Stuttgart: Poeschl.

Grunert, K. G. (1995). Food quality: A means-end perspective. Food Quality and Preference6, 171-176

Grunert, K. G., Bisp, S. \& Brunsø, K. (1995). Competitor intelligence: Erhvervslivet kunde hos CIA? Ledelse i Dag 4(4), 24-32.

Grunert, K. G., Brunsø, K. \& Bisp, S. (in press). Food-related life style: Development of a cross-culturally valid instrument for market surveillance. In: L. Kahle \& C. Chiagouris (Eds.). Values, lifestyles, and psychographics. Hillsdale, NJ : Erlbaum.

Grunert, K. G. \& Ellegaard, C. (1993). The concept of key success factors: Theory and method. In: M. J. Baker (E d.). Perspectives on marketing management, pp. 245-274. Chichester: J ohn Wiley \& Sons Ltd.

Grunert, K. G. \& Grunert, S. C. (in press). Measuring subjective meaning structures by the laddering method: Theoretical considerations and methodological problems. International J ournal of Research in Marketing.

Grunert, K. G., Grunert, S. C., Glatzer, W. \& Imkamp, H. (in press). The changing consumer in Germany. International J ournal of Research in Marketing, 12(4).

Grunert, K. G. \& Brunsø, K. (1995). Identifying food-related life style segments in Germany by a cross-culturally valid scaling device. Schriftenrei he der AGEV, 10, 132136.

Grunert, S. C., Grunert, K. G. \& Kristensen K. (1994). Une méthode d'estimation de la validité interculturelle des instruments de mesure: le cas de la mesure des valeurs des consommateurs par la liste des valeurs LOV. Recherches eA Application en Marketing, 5-28.

Grunert, S. C. (1995). Symbols and schemas in emotional eating. Ernährungs-Umschau $42,121-125$.

Harmsen, H. (1994). Improving market oriented product development in Danish food companies. In: P. C. de Weerd-Nederhof, I. C. Kerssens-van Drongelen \& R. Verganti (Eds.), Managing the R\&D process. Twente: Twente Quality Centre.

J elsøe, E., Land, B. \& Lassen, J. (1993). Do consumers have influence on food production. In: U. Kjærnæs, L. Holm, M. Ekström, E. L. Fürst \& R. Prättälä (Eds.). Regulating markets regulating people - On food and nutrition policy, pp. 123-136. Oslo: Novus Forlag.

Kristensen, K., Kanji, G. K \& Dahlgaard, J. J . (1992) On measurement of customer satisfaction, Total Quality Management, 3 (2), 123-128. 
Kristensen, P. S. (1992). Flying prototypes: Productions departments' direct interaction with external customers, International J ournal of Operations \& Production Management, 12 (7/8), 197-212.

Kristensen, P. S. (1992). Product development strategy in the Danish agricultural complex: Global interaction with clusters of marketing excellence, TheJ ournal of Food and Agribusiness Marketing (4) 3, 107-118.

Martensen, A. (1993). A model for marketing planning for new products. Marketing and Research Today (November), 247-267.

Poulsen, C. S., J uhl, H. J ., Kristensen, K., Bech, A. C. \& Engelund, E. (forthcoming) Quality guidance and quality formation. Food Quality and Preference.

Søgaard, V. (1994). Power-dependence relations in federative organizations, Annals of Public and Cooperative E conomics (1), 103-125.

Thøgersen, J. (1994). A model of recycling behaviour. With evidence from Danish source separation programmes. International J ournal of Research in Marketing, 11, 145-163.

Thøgersen, J. (in press). The behavioural aspect of recycling. The roots of support and participation. In: P. Vogas (Ed.). Recycling: All the latest evolution, pp. XXX. Athens: Papazisis S. A.

Thøgersen, J . (1994). Recyding of consumer waste. A behavioural science approach to environmental protection policy. In: B. Bürgenmeier, (Ed.). Economy, environment and technol ogy: A soci oeconomic approach, pp. 51-73. Armonk: M. E. Sharpe, Inc.

Thøgersen, J . (in press). Wasteful food consumption - Trends in food and packaging waste, The Scandinavian J ournal of Management.

Furthermore there are a number of project papers, which are not available to the public. 